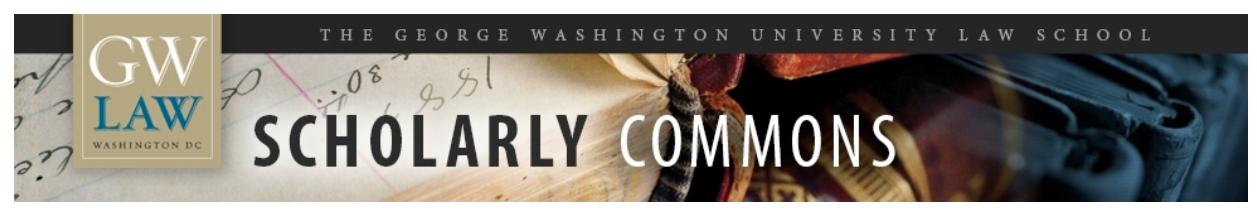

\title{
Consumer Bankruptcy Fraud and the Reliance on Advice of Counsel Argument
}

\author{
Gregory E. Maggs \\ George Washington University Law School, gmaggs@law.gwu.edu
}

Follow this and additional works at: https://scholarship.law.gwu.edu/faculty_publications

Part of the Law Commons

\section{Recommended Citation}

Maggs, Gregory E., Consumer Bankruptcy Fraud and the Reliance on Advice of Counsel Argument (1995). Gregory E. Maggs, Consumer Bankruptcy Fraud and the Reliance on Advice of Counsel Argument, 69 Am. Bankr. L.J. 1 (1995); GWU Law School Public Law Research Paper No. 2017-33; GWU Legal Studies Research Paper No. 2017-33. Available at SSRN: http://ssrn.com/abstract=2955797

This Article is brought to you for free and open access by the Faculty Scholarship at Scholarly Commons. It has been accepted for inclusion in GW Law Faculty Publications \& Other Works by an authorized administrator of Scholarly Commons. For more information, please contact spagel@law.gwu.edu. 


\title{
Consumer Bankruptcy Fraud And The "Reliance on Advice of Counsel" Argument
}

\author{
by
}

Gregory E. Maggs*

When sued or prosecuted for committing bankruptcy fraud, consumer bankruptcy debtors sometimes argue they should not be punished because they acted with the advice of counsel. For example, they may assert that even though they concealed certain assets or made false statements, their lawyers told them that the law permitted these actions. Despite considerable litigation on the subject, there is little agreement as to whether courts must accept this "reliance argument" in bankruptcy fraud cases.

The federal courts of appeals have taken different positions on whether reliance on advice of counsel can excuse bankruptcy fraud. The Courts of Appeals for the Eighth and Ninth Circuits agree that advice of counsel may excuse some kinds of fraud, but disagree about exactly what a debtor must show. ${ }^{1}$ The Court of Appeals for the First Circuit has taken a somewhat different position, rejecting the reliance argument in circumstances in which the other courts have not. ${ }^{2}$ Many lower courts also have weighed in with different views. ${ }^{3}$

This Article seeks to clarify the existing law and recommend changes to the governing statutes. The first three Parts of the Article serve a descriptive function. Part Iprovidesan overview of consumer bankruptcy fraudand describeshow debtors perpetrate fraud and how attorneys may be assisting them. It also explains how the Bankruptcy Code and the Federal Criminal Code currently seek to deter fraud and to punish debtors who commit it.

*Associate Professor of Law, The George Washington University National Law Center. The Regents' Research Professorship in Bankruptcy Law and Practice at the University of Texas provided generous financial support for the research and writing of this article while the author was an AssistantProfessor of Law at the University of Texas School of Law. The author is grateful to his colleagues at the National Law Center for giving him helpful suggestions at a "Works in Progress" discussion. The author especially also would like to thank the Hon. Steven W. Rhodes for his careful editorial work and Steve Feldman for providing detailed comments on an earlier draft.

'See Norwest Bank Nebraska v. Tveten (In re Tveten), 848 F.2d 871 (8th Cir. 1988); First Beverly Bank v. Adeeb (In re Adeeb), 787 F.2d 1339 (9th Cir. 1986); City Nat'l Bank v. Bateman (In re Bateman), 646 F.2d 1220 (8th Cir. 1981). For a detailed description of these cases, see infra Part III.B.

${ }^{2}$ See Boroff v. Tully (In re Tully), 818 F.2d 106 (1st Cir. 1987). For more explanation, see infra Part III.B.

${ }^{3}$ See infra Part III.B. 
Part II reports how courts generally have treated the reliance argument in contexts outside of bankruptcy. It demonstrates that non-bankruptcy law has traditionally not accepted the reliance on advice of counsel argument as an affirmative defense. Instead, in criminal and tort cases, evidence of reliance has generally served only to rebut proof that a defendant may have acted with a specific intent, such as an intent to defraud, or that a defendant may have acted unreasonably.

Part III describes how courts have treated the reliance argument in bankruptcy cases. In the nineteenth and early twentieth centuries, courts within the bankruptcy context agreed with the approach of courts outside of bankruptcy. In particular, the bankruptcy courts generally held that evidence of reliance on counsel was relevant only to the extent that it might show that elements of a charged bankruptcy offense were not satisfied. Some courts, however, have recently departed from this position in bankruptcy cases and have created a separate reliance on the advice of counsel doctrine with requirements not directly related to the elements of bankruptcy offenses.

The fourth and fifth Parts of the Article serve prescriptive roles. Part IV sets forth the author's view of how courts should treat the reliance argument in bankruptcy cases under existing statutes. It argues that instead of creating a separate advice of counsel doctrine or treating the argument like an affirmative defense, courts in bankruptcy cases generally should treat the reliance argument as they historically have treated it. In particular, they should view reliance on counsel only as evidence of the debtor's knowledge or intention or the reasonableness of the debtor's actions.

Part V proposes that Congress should reform the current law in two principal ways. First, Congress should adopt several modest measures to deter attorneys from improperly advising clients. These measures include imposing a requirement that a debtor's reliance on counsel must be reasonable, and a requirement that debtors and their lawyers sign a form that describes the bankruptcy disclosure requirements and the prohibitions against bankruptcy fraud. Second, Congress should amend existing bankruptcy fraud statutes to address explicitly the reliance argument. Specifically, Congress should take steps similar to those taken by the Department of Treasury to reduce litigation over reliance on advice of counsel in tax fraud cases.

\section{OVERVIEW OF CONSUMER BANKRUPTCY FRAUD}

Consumer debtors have a choice between two different forms of bankruptcy relief. Under Chapter 7 of the Bankruptcy Code, debtors surrender all of their assets to a bankruptcy trustee. ${ }^{4}$ The Bankruptcy Code then specifies which assets the trustee should distribute to creditors ${ }^{5}$ and which assets the trustee should return to

${ }^{4}$ See 11 U.S.C. $\$ 541$ (a) (1988) (creating a bankruptcy "estate" including virtually all of the debtor's assets); id. $\$ 704(1)$ (requiring the trustee to collect all of the property of the estate); id. $\$ 521(3)$ (requiring the debtor to cooperate with the trustee).

'See id. $\$ 726$ (stating distribution rules of the debtor's property). 
the debtors as exempt from distribution. ${ }^{6}$ Under Chapter 13 , debtors may keep their assets, but must surrender their disposable income over a period of time. ${ }^{7}$ Pursuant to a plan confirmed by the bankruptcy court, the trustee uses this income to pay creditors. ${ }^{8}$ Under both Chapter 7 and 13, in exchange for the debtor's cooperation, the Bankruptcy Code provides that the debtor will receive a discharge of most types of debts that the debtor owed at the time of the bankruptcy filing, whether or not the trustee has been able to pay the creditors in full.

Perhaps because of thissimplicity of design, the consumer bankruptcy system can handle extraordinarily large numbers of debtors and quantities of money. Consumer debtors declare bankruptcy by the hundreds of thousands each year. ${ }^{10}$ In processing these bankruptcies, trustees distribute billions of dollars of assets to creditors and bankruptcy courts discharge billions of dollars of unpaid debts. ${ }^{11}$ Unfortunately, not all participants play by the rules.

\section{A. BankRuptcy Fraud AND the Role of Counsel}

Consumer debtors frequently attempt to cheat the bankruptcy system by devising ways to hide their property or income from the bankruptcy trustee, thereby keeping it from their creditors. Most schemes require little imagination or cunning. Some debtors give their property to relatives prior to filing a bankruptcy petition. ${ }^{2}$ Others lie or fail to make a full disclosure about what they own or earn in documents submitted in court. ${ }^{13}$ Whatever the technique, the debtor's goal is always to obtain a discharge at the least possible personal cost.

Consumer debtors who are inclined to commit bankruptcy fraud require little advice on how to do it. When a consumer debtor enters a law office for representation in filing a bankruptcy petition, an attorney or paralegal instructs the client to fill out

'See id. $\$ 522(d)$ (specifying exempt property under the federal scheme). Many states, however, have "opted-out" of the federal exemptions and debtors in these states can exempt property described by nonbankruptcy law. See id. $\$ 522(b)$.

${ }^{7}$ See id. $\S 1306(a)(2)$ (explaining that property of the chapter 13 estate includes earnings from services performed by debtor).

${ }^{8}$ See id. $\$ 1325$ (describing the plan for distributing the debtor's disposable income).

'See 11 U.S.C. $\$ \$ 727(a), 1328(a)$ (1988). For types of nondischargeable debts, see id. \$\$ 523, 1328(a)(1)(3). For a summary of various policies embodied in the Bankruptcy Code, including the debtor's discharge, see Margaret Howard, The Theory of Discharge in Consumer Bankruptcy, 48 OHIO ST. L.J. 1047 (1987).

${ }^{10}$ See Director of the Admin. Office of the United States Courts AnN. Rep. app. 1 (1994) (reporting that 879,231 bankruptcies were filed in 1993).

"The government does not keep statistics on these figures, but other information makes rough estimates possible. See Teresa A. Sullivan et al., As We Forgive Our Debtors: Bankruptcy and Consumer Credit IN AMERTCA 14 n.5 (1989).

${ }^{12}$ See, e.g., Ferrato v. Ferrato (In re Ferrato), 156 B.R. 83, 86 (Bankr. M.D. Fla. 1993) (involving a fraudulent transfer to debtor's father-in-law); Lindley v. Lindley (In re Lindley), 121 B.R. 81, 88 (Bankr.N.D. Okla. 1990) (involving a fraudulent transfer to debtor's father, brother, and sister).

"See, eg., Vaughn v. Aboukhater (In re Aboukhater), 165 B.R. 904, 910 (Bankr. 9th Cir. 1994) (failing to disclose ownership of residence); Citibank v. Williams (In re Williams), 159 B.R. 648, 660 (Bankr. D.R.I. 1993) (failing to disclose ownership of personal property). 
a set of schedules. One of the schedules asks for a list of all of the debtor's property. ${ }^{14}$ The debtor does not need a law degree to figure out that the bankruptcy trustee assigned to the case will not be able to distribute to creditors any property or money that the trustee does not know about and cannot find. Some debtors, as a result, simply lie on their bankruptcy schedules. ${ }^{15}$

Nevertheless, attorneys play a significant role in consumer bankruptcy fraud. Despite the risk of disbarment and prison, lawyers may intentionally advise debtors to conceal assets or commit other forms of fraud. The United States Attorney in Chicago has obtained convictions of seven attorneys for bankruptcy fraud in recent years ${ }^{16}$ Although the number of lawyers who knowingly participate in fraud is quite small, just a few of them can create major problems. One bankruptcy trustee in Sacramento recently complained that a half-dozen attorneys were responsible for dozens of questionable cases. ${ }^{17}$

Other attorneys instruct debtors to take prohibited acts simply by mistake. Debtors contemplating bankruptcy ask a host of questions about what they can do with their property and what they must list on their schedules. Somelawyers answer incorrectly because they misunderstand the questions, or because they do not understand the law, or because the law is unclear. ${ }^{18}$

Still other attorneys may give debtors proper legal advice, but later agree to cover for debtors who commit fraud without their knowledge. For example, an attorney might tell the court that the client was mistakenly left with the impression that the law did not require identification or surrender of particular assets. Although the purported mistake may reflect poorly on the attorney, the client will not complain if the lawyer's assumption of responsibility protects the client from punishment. $^{19}$

\section{B. Penalties for Bankruptcy Fraud}

Debtors found to have committed bankruptcy fraud face three kinds of penalties. First, they may forfeit their right to receive a discharge of their indebtedness. Second, they may incur criminal sanctions. Third, they may lose their ability to claim exemptions in any property that they have tried to hide or give away.

\footnotetext{
${ }^{14}$ See Fed. R. BANKR. P. Form 6.

${ }^{15}$ See, e.g., Barnett Bank v. Muscatell (In re Muscatell), 113 B.R. 72,75 (Bankr. M.D. Fla. 1990); Butler v. Ingle (In re Ingle), 70 B.R. 979, 984 (Bankr. E.D.N.C. 1987); Day v. Ailetcher (In re Ailetcher), 49 B.R. 681, 685 (Bankr. D. Haw. 1985) (making a false statement on schedules without professional advice).

${ }^{16}$ John F. Rooney, Officials Cite Surge in Bankruptcy Fraud Here, Chr. Dally L. Bull., Oct. 15, 1993, at 3. ${ }^{17}$ See Rami Grunbaum, Haven for Bankruptcy Fraud, Bus. J. SACRAMENTO, Jul. 27, 1987, $\$ 1$, at 1.

${ }^{18}$ See, e.g., American State Bank v. Montgomery (In re Montgomery), 86 B.R. 948, 958 (Bankr. N.D. Ind. 1988) (excusing a false statement by the debtor because of debtor's attorney's ignorance of the law).

${ }^{19}$ One bankruptcy court has lamented that, when fraudulent acts occur, bankruptcy attorneys quickly say: " 'Blame me, not the debtor-it was due to mistake and inadvertence.' "Raymos v. Collins (In re Collins), 19 B.R. 874, 877 (Bankr. M.D. Fla. 1982). See also Boroff v. Tully (In re Tully), 818 F.2d 106, 111 (1st Cir. 1987) (discussing "an attorney's willingness to bear the burden of reproach").
} 


\section{Denial of Discharge}

Bankruptcy benefits debtors primarily by freeing them from their pre-bankruptcy debts. Debtors who declare bankruptcy but donot receivea dischargelose this benefit, but still have to turn over all of their non-exempt assets or disposable income to the bankruptcy trustee for distribution to creditors. These debtors thus find themselves worse off than had they not filed bankruptcy.

The denial of discharge penalty appears in $\$ 727$ of the Bankruptcy Code ${ }^{20}$ The first clause of $\$ 727$ (a) states the general rule that a debtor will receive a discharge of all dischargeable pre-bankruptcy debts. ${ }^{21}$ Subsection (a) then lists ten exceptions in which the customary discharge will be denied. Bankruptcy fraud cases involve the four exceptions stated in paragraphs (a)(2) through (a)(5) of $\$ 727.22$

Both paragraphs (a)(2) and (a)(4) concern misdeeds committed by a debtor with a malevolent intent. Paragraph (a)(2) denies a discharge to debtors who have transferred or concealed property "with intent to hinder, delay, or defraud" a creditor or trustee. ${ }^{23}$ Similarly, paragraph (a)(4) denies a discharge to debtors who have "knowingly or fraudulently" made a false oath or account or who have witheld financial information. ${ }^{24}$ As discussed more fully below, courts disagree about whether these exceptions apply when debtors prove that they undertook the prohibited acts in reliance on the advice of counsel.

Paragraphs (a)(3) and (a)(5) deny a discharge to a debtor who has committed

\footnotetext{
${ }^{20}$ See 11 U.S.C. $\$ 727$ (1988). Section 727 applies only in cases in which the debtor seeks to liquidate his or her assets. When the debtor seeks to repay debts out of future income, $\$ 1322(\mathrm{~b})$ of the Bankruptcy Code states that a court may revoke a discharge obtained by fraud, but does not define fraud. See id. $\$ 1322(b)$. Presumably, courts should look to the standards set forth in $\$ 727$.

${ }^{21}$ See id. $\$ 727$ (a). Another provision of the Bankruptcy Code identifies certain debts that are nondischargeable. See id. \$523(a).

${ }^{22}$ The six remaining exceptions have little relevance in bankruptcy fraud cases.

${ }^{23} 11$ U.S.C. $\$ 727(\mathrm{a})(2)$ (1988). This paragraph provides that the debtor cannot receive a discharge if:
}

[T] he debtor, with intent to hinder, delay, or defraud a creditor or an officer of the estate charged with custody of property under this title, has transferred, removed, destroyed, mutilated, or concealed, or has permitted to be transferred, removed, destroyed, mutilated, or concealed-

(A) property of the debtor, within one year before the date of the filing of the petition; or

Id.

(B) property of the estate, after the date of the filing of the petition.

${ }^{24} I d . \$ 727(a)(4)$. This paragraph provides that the debtor cannot receive a discharge if:

[T] he debtor knowingly and fraudulently, in or in connection with the case-

(A) made a false oath or account;

(B) presented or used a false claim;

(C) gave, offered, received, or attempted to obtain money, property, or advantage, or a promise of money, property, or advantage, for acting or forbearing to act; or

(D) withheld from an officer of the estate entitled to possession under this title, any recorded information, including books, documents, records, and papers, relating to the

Id. debtor's property or financial affairs. 
certain other improper acts, without any explicit reference to the debtor's state of mind. These acts include concealing, destroying, or falsifying business records, ${ }^{25}$ and failing to explain satisfactorily a loss of assets. ${ }^{26}$

\section{Criminal Sanctions}

Section 152 of the Federal Criminal Code ("Criminal Code" ${ }^{27}$ makes nine different acts in bankruptcy cases crimes punishable by up to five years' imprisonment or $\$ 5,000$ in fines. The first, second, third, seventh, eighth, and ninth paragraphs of $\$ 152$ criminalize distinct forms of fraud that are comparable to those identified in paragraphs (a)(2) through (a)(5) of $\$ 727$ of the Bankruptcy Code, including concealment of assets and destruction of records. ${ }^{28}$ One element in each of these crimes

${ }^{25}$ Paragraph (a)(3) states that a court may not grant a discharge if:

[T] he debtor has concealed, destroyed, mutilated, falsified, or failed to keep or preserve any recorded information, including books, documents, records, and papers, from which the debtor's financial condition or business transactions might be ascertained, unless such act or failure to act was justified under all of the circumstances of the case.

Id. $\$ 727(\mathrm{a})(3)$.

${ }^{26}$ Paragraph (a)(5) requires a court to deny a debtor's discharge if the debtor has failed to explain satisfactorily, before determination of denial of discharge under this paragraph, any loss of assets or deficiency of assets to meet the debtor's liabilities." Id. \$ 727(a)(5).

${ }^{27} 18$ U.S.C. $\$ 152$ (1988). Section 152 has existed in various forms since 1948 . Congress recently amended the section, principally to add references to United States Trustees. See Bankruptcy Reform Act of 1994, Pub. L. No. 103-394, § 312(a)(1)(a), 108 Stat. 4106, 4138-4139 (1994) (to be codified at 18 U.S.C. § 152).

${ }^{28}$ The amended text of $\S 152$ provides in part:

\section{A person who-}

(1) knowingly and fraudulently conceals from a custodian, trustee, marshal, or other officer of the court charged with the control or custody of property, or, in connection with a case under title 11, from creditors or the United States Trustee, any property belonging to the estate of a debtor;

(2) knowingly and fraudulently makes a false oath or account in or in relation to any case under title 11 ;

(3) knowingly and fraudulently makes a false declaration, certificate, verification, or statement under penalty of perjury as permitted under section 1746 of title 28 , in or in relation to any case under title 11 ;

(7) in a personal capacity or as an agent or officer of any person or corporation, in contemplation of a case under title 11 by or against the person or any other person or corporation, or with intent to defeat the provisions of title 11 , knowingly and fraudulently transfers or conceals any of his property or the property of such other person or corporation;

(8) after the filing of a case under title 11 or in contemplation thereof, knowingly and fraudulently conceals, destroys, mutilates, falsifies, or makes a false entry in any recorded information (including books, documents, records, and papers) relating to the property or financial affairs of a debtor; or

(9) after the filing of a case under title 11, knowingly and fraudulently withholds from a custodian, trustee, marshal, or other officer of the court or a United States Trustee entitled to its possession, any recorded information (including books, documents, records, and papers) relating to the property or financial affairs of a debtor, shall be fined not more than $\$ 5,000$, imprisoned not more than 5 years, or both."

18 U.S.C. $\$ 152$ (1994). 
is that the debtor has acted "knowingly and fraudulently." ${ }^{29}$ Section 152 does not address reliance on advice of counsel, and courts havenot determined its precise effect.

A few debtors have received lengthy prison sentences for violating $\S 152,{ }^{30}$ but criminal prosecutions for bankruptcy fraud have been fairly rare. ${ }^{31}$ In the 1992 fiscal year, for example, federal prosecutors obtained only 137 indictments under $\$ 152 .{ }^{32}$ Prosecutors may hesitate to press criminal charges for several reasons. In some cases, the prosecutor may conclude that a denial of discharge under $\$ 727$ of the Bankruptcy Code imposes a sufficiently harsh penalty on the debtor. Alternatively, the prosecutor may simply decide not to expend limited resources on a minor offense. An anonymous government official has stated that United States Attorneys will not prosecute bankruptcy fraud cases involving less than $\$ 100,000 .^{33}$

\section{Loss of the Right to Claim Exemptions}

The Bankruptcy Code requires debtors to surrender all of their property to a bankruptcy trustee upon filing a bankruptcy petition. ${ }^{34}$ Debtors who cooperate and turn over their property to the trustee have the right to claim some of it as exempt from distribution to creditors. ${ }^{35}$ If the trustee has to go after property that the debtor has concealed or voluntarily transferred to third-parties, however, $\S 522(\mathrm{~g})(1)$ of the Bankruptcy Code strips the debtor of this right. ${ }^{36}$ The author has not found any cases in which debtors have attempted to escape this sanction by arguing that they merely transferred or concealed the property in reliance on advice of counsel.

\section{JUDICIAL TREATMENT OF THE RELIANCE ARGUMENT INNON-BANKRUPTCY CASES}

Virtually every lawyer is familiar with the maxim, "Ignorance of the law is no excuse." Our legal system generally expects everyone, with or without legal counsel, to know the requirements of the law. ${ }^{37}$ For this reason, it may seem inappropriate for the law to permit a debtor to avoid the usual penalties for misconduct by showing that the misconduct resulted from bad legal advice. Yet, excusing debtors who rely on counsel is not necessarily inconsistent with well-established legal principles.

For over one hundred years, in a variety of contexts in non-bankruptcy cases,

\footnotetext{
${ }^{29}$ See id.

${ }^{30}$ See Sharon Walsh, Bankruptcy Fraud Rises as Debtors Hide Assets, WASH. Post, July 13, 1991, at A1.

${ }^{31}$ See generally Ralph C. McCullough, Bankruptcy Fraud: Crime Without Punishment, 96 CoM. L.J. 257

${ }^{32}$ See Rooney, supra note 16, at 3.In 1989, grand juries returned only 75 indictments. See McCullough, supra note 31 , at 258 n.9.

${ }^{33}$ See Grunbaum, supra note 17 , at 1.

${ }^{34}$ See supra note 4.

${ }^{35}$ See 11 U.S.C. $\$ 522(b)(1988)$.

${ }^{36}$ See id. § 522(g)(1). See also Goldman v. Rimmel (In re Goldman), 111 B.R. 230, 233 (E.D. Mo. 1990) (explaining the application of $\$ 522(\mathrm{~g})(1)$ ).

${ }^{37}$ See Cheek v. United States, 498 U.S. 192, 199 (1991); Oliver W. Holmes, The COMMON LAW 47-48 (1881) (arguing that public policy requires sacrificing the individual for society's overall benefit).
} (1991). 
courts have occasionally allowed parties to escape punishment by proving that they acted in reliance on the advice of counsel ${ }^{38}$ Although the decisions in these cases do not control the interpretation of the Bankruptcy Code, they do provide useful insight into how and why the reliance argument might prevent a denial of discharge or criminal punishment for bankruptcy fraud.

\section{A. Theory and Limitations of the Reliance Argument}

Courts and commentators have discussed the details of the reliance argument remarkably little. ${ }^{39}$ The cases, however, make it clear that the reliance argument is generally not a separate or affirmative defense. Instead, in the vast majority of cases, proof that the defendant followed a lawyer's instructions serves only to negate some element of a charged tort or criminal offense. ${ }^{40}$ Typically, a defendant will deny acting in bad faith or with a specific intent to do harm because an attorney had recommended the conduct in question.

For instance, in Bursten $v$. United States, ${ }^{41}$ a jury convicted the defendant of tax evasion after he falsely declared that he had no income for a particular year. The defendant appealed, asserting that he had merely followed his attorney's advice in completing his tax returns. The Court of Appeals for the Fifth Circuit reversed the conviction because the trial court's jury instructions did not refer to the reliance argument. ${ }^{42}$ The court explained that the prosecution had a duty to prove that the defendant "willfully filed a false income tax return with intent to defraud the Government." ${ }^{43}$ The court then reasoned that "if the jury believed that appellant honestly relied on the advice of his tax counsel," it might have found that he lacked

\footnotetext{
${ }^{38}$ See, e.g., Buchanan v. State, 5 So.617,618 (Miss. 1889); Neff 's Appeal, $57 \mathrm{~Pa} .91,96$ (1868). But see Tuttle v. Gilmore, 36 N.J. Eq. 617,624 (1883) (rejecting advice of counsel argument where defendant did not actually rely).

${ }^{39}$ The West Virginia Supreme Court of Appeals has lamented that " $[r]$ eliance on advice of counsel as a defense is a subject that does not appear to have been extensively discussed by the courts." Powers v. Goodwin, 324 S.E.2d 701,705 (W.Va. 1984). For the most thorough (and most frequently cited) academic analysis of cases accepting the argument, see Douglas W. Hawes \& Thomas J. Sherrard, Reliance on Advice of Counsel as a Defense in Corporate and Securities Cases, 62 VA. L. REv. 1, 6-40 (1976). See also Bevis Longstreth, Reliance on Advice of Counsel as a Defense to Securities Law Violations, 37 Bus. LAw. 1185 (1982); James C. Nielsen, Advice of Counsel in Insurance Bad Faith Litigation: A Substantive Framework for Pleading. Discovery, and Proof, 25 TORT \& INs. L.J. 533 (1989); Thomas L. Preston, Advice of Counsel as a Defense, 28 VA. L. Rev. 26 (1941); Note, Reliance on the Advice of Counsel, 70 Y ALE L.J. 978 (1961).

${ }^{+0} A$ s two commentators have explained:
}

[R]eliance on advice of counsel has been allowed primarily to prove that a defendant acted in good faith or with due care when the breach of those standards of conduct constitutes an element of the offense with which the defendant is charged. ... [I]t is not in itself a complete and absolute defense.

Hawes \& Sherrard, supra note 39, at 7-8 (footnotes omitted). Even though the argument does not serve as an actual defense, many courts either incorrectly or for simplicity refer to it as a defense. See id. at 8 .

4395 F.2d 976 (5th Cir. 1968).

${ }^{42}$ See id. at 981 .

${ }^{43} I d$. 
the required state of mind.4

Other courts have applied similar reasoning in cases involving embezzlement, ${ }^{45}$ improper handling of trust estates, ${ }^{46}$ antitrust violations, ${ }^{47}$ patent infringement, ${ }^{48}$ and many others as well. ${ }^{9}$

The reliance argument outside the bankruptcy context appears to have two important limitations. First, advice of counsel cannotexcuse a defendant from liability if other evidence demonstrates the requisite mensrea for a crime or tort. As the Fourth Circuit explained in a mail fraud case:

That the defendants proceeded under advice of a lawyer is a fact to be considered together with other facts in determining the question of the defendants' good faith, but legal advice does not under all circumstances constitute an impregnable wall of defense. To hold otherwise would be to say that no matter how violative of law a defendant's conduct may be, and regardless of consciousness of wrongdoing on his part and his adviser's, the advice confers immunity. ${ }^{50}$

Reliance on advice of counsel, in short, serves as only one factor in determining a defendant's mental state..$^{51}$

Second, advice of counsel cannot excuse a defendant from liability for an offense that does not include as an element bad faith, specific intent, or the exercise of any standard of care. The case of Licavoli v. United States ${ }^{52}$ is a straightforward example

\footnotetext{
${ }^{4} I$ Id. The Department of Treasury has since issued regulations codifying some of the rules on advice of counsel in tax cases. See Substantial Understatement of Income Tax, 26 C.F.R. § 1.6662-4(g) (1993).

${ }^{45}$ See, e.g., State v. Patterson, 71 P. 860 (Kan. 1903).

${ }^{+5}$ See, e.g., Dill v. Boston Safe Deposit \& Trust Co., 175 N.E.2d 911 (Mass. 1961).

${ }^{47}$ See, e.g., Stark v. New York Stock Exch., 346 F. Supp. 217 (S.D.N.Y.), aff'd, 466 F.2d 743 (2d Cir. 1972).

${ }^{48}$ See, e.g., Union Carbide Corp. v. Graver Tank \& Mfg. Co., 282 F.2d 653, 663 (7th Cir. 1960), cert. denied, 365 U.S. 812 (1961).

${ }^{4}$ For additional citations, see Hawes \& Sherrard, supra note 39, at 9-11; Note, supra note 39, at 978-79.

${ }^{50}$ Linden v. United States, 254 F.2d 560, 568 (4th Cir. 1958) (citations omitted).

stSee S.E.C. v. Savoy Indus., Inc., 665 F.2d 1310, 1314 n.28 (D.C. Cir. 1981)("Even when established, such reliance [on counsel] does not operate as an automatic defense, but is only one factor to be considered in determining the propriety of [liability]."); Powers v. Goodwin, 324 S.E.2d 701, 706 (W. Va. 1984) ("[I]t is generally held that reliance on counsel is not an absolute defense to charges that a person is acting unlawfully or negligently."); Hawes \& Sherrard, supra note 39, at 7 ("reliance is recognized only as a factor or circumstance tending to show the defendant's good faith or exercise of due care; it is not in itself a complete and absolute defense.").

The tort of malicious prosecution is a possible exception to this rule. To win a malicious prosecution case, a plaintiff must show that a defendant lacked probable cause for initiating or procuring a prosecution. RESTATEMENT (SECOND) OF TORTS $§ 661$ (1989). A defendant had probable cause only if he or she "correctly or reasonably" believed that the accused had committed an offense. Id. $\$ 662$. In such cases, "the advice of an attorney at law ... is conclusive of theexistence of probable cause" provided that the defendant seeks the advice in good faith after a full disclosure of the facts. Id. \$ 666(1). See also Hanson v. Couch, 360 So. $2 \mathrm{~d} 942$ (Ala. 1978); Baker v. Larson, 25 P.2d 375 (Kan. 1933); Powers, 324 S.E.2d at 706; Petrie v. Roberts, 8 N.W.2d 355 (Wis. 1943).

52294 F.2d 207 (D.C. Cir.), cert. denied, 366 U.S. 936 (1961).
} 
of this. On the advice of counsel, the defendant refused to appear before a Senate committee, and was convicted of "willfully" making default on a congressional subpoena. ${ }^{53}$ On appeal, the court gave no weight to the defendant's assertion that he had relied on the advice of counsel in disobeying the subpoena. The court stated:

All that is needed ... is a deliberate intention to do the act. Advice of counsel does not immunize that simple intention. It might immunize if evil motive or purpose were an element of the offense. But such motive or purpose is not an element [of the offense at issue.$^{54}$

In such cases, advice of counsel at best serves as a mitigating factor in determining the appropriate punishment. ${ }^{55}$

\section{B. "Elements" of the Reliance Argument}

Several commentators have attempted to develop a list of elements that a defendant must prove when making the reliance argument. One author, for example, has suggested that a defendant must show that he or she:(1) accurately relied, (2) in good faith, (3) on advice of competent counsel,(4)concerning a question of law. ${ }^{56}$ Two other writers would add that the defendant must have: (5) acted with due or reasonable care, ${ }^{57}$ and (6) disclosed all of the facts to his or her attorney. ${ }^{58}$

Some courts appear to agree with these commentators that the reliance argument has a fixed set of elements that a defendant must prove. A few cases, for example, have rejected the reliance argument because the defendant failed to follow a lawyer's advice accurately. ${ }^{59}$ Other cases have faulted defendants for not relying in good faith ${ }^{60}$ or in a reasonable manner. ${ }^{61}$ Still, other cases have declined to absolve defendants from liability when they have not made full disclosures to their lawyers. ${ }^{62}$

The view that the reliance argument has rigid requirements of proof, however, does not accord with the general theory of why reliance on advice of counsel may protect a debtor from punishment. As shown above, reliance on the advice of counsel is not an affirmative defense. Instead, when a defendant introduces evidence of reliance on counsel, the defendant is usually trying to negate an element of a particular crime or tort, such as fraudulent intent.

Even if the defendant cannot show all of the elements suggested by the

${ }^{53} I d$ at 209.

${ }^{54}$ Id.

${ }^{55}$ See Note, supra note 39 , at 978-79.

${ }^{56} \mathrm{See}$ id. at 979-85.

${ }^{57}$ See Hawes \& Sherrard, supra note 39, at 19.

${ }^{58}$ See id. at 29.

${ }^{59}$ See, e.g., United States v. Custer Channel Wing Corp., 376 F.2d 675, 677 (4th Cir.), cert. denied, 389 U.S. 850 (1967).

${ }^{80}$ See, e.g., Adkin v. Pillen, 100 N.W. 176 (Mich. 1904).

${ }^{61}$ See, e.g. James v. West, 65 N.E. 156 (Ohio 1902).

${ }^{62}$ See, e.g., Carbaugh v. Peat, 189 N.E.2d 14, 15 (Ill. App. Ct. 1963). 
commentators, the reliance argument may still help the defendant. For example, assume that a defendant charged with tax fraud was particularly unknowledgeable and therefore had relied on advice by a tax lawyer that no client of ordinary intelligence would have believed. The defendant's reliance on that advice still might help to show that the defendant did not have an intent to defraud, even if the defendant's reliance was unreasonable.

In other words, legal advice received by a defendant may affect the defendant's state of mind, whether or not that advice is reasonable, or was accurately followed, or was given by a competent attorney. Accordingly, there is no basis to conclude that a defendant should be required to show any particular elements to prove reliance. At the same time, to the extent that the defendant shows reasonableness, full disclosure, competence of counsel, and other similar factors, a fact finder might find the reliance argument more credible.

\section{JUDICIAL TREATMENT OF THE RELIANCE ARGUMENT IN BANKRUPTCY CASES}

Each of the five federal bankruptcy laws enacted since the founding of the Republic have attempted to establish orderly procedures for taking assets from debtors and distributing them to creditors. Because bankruptcy debtors have the most to lose from the smooth functioning of these laws, they have throughout history faced the temptation to thwart the process by concealing or giving away their property. Congress, in turn, has regularly sought to deter debtors' misbehavior by imposing civil and criminal penalties for bankruptcy fraud.

For over a century, debtors have attempted to avoid punishment by arguing that they acted in reliance on advice of counsel. Cases from different periods reveal that the treatment of the argument has changed over time. From the earliest decisions in the 1840s until the mid-part of this century, courts uniformly viewed reliance on legal advice in the traditional manner described in Part II above-not as an absolute defense, but merely as evidence that the debtor lacked a malevolent intent. A current leading bankruptcy treatise still reports this view. ${ }^{63}$ Careful study of recent cases, however, shows that courts now treat the advice of counsel argument in a less consistent manner.

\section{A. Historical TREATMENT}

Congress enacted the first federal bankruptcy law in $1800 . .^{64} \mathrm{It}$ produced no reported bankruptcy fraud cases and was repealed in $1803 .{ }^{65}$ In 1841 , Congress

\footnotetext{
${ }^{63}$ See 1 LAWRENCE P. KNng, Collier ON BANKRUPTCY I 7A.04[1] [a], at 7A-147(1994)("Advice of counsel is not a separate or affirmative defense; rather, the fact that the defendant sought legal adviceand followed it tends to negate an inference that the defendant committed the actions fraudulently.').

${ }^{4}$ See Act of April 4, 1800, ch. 19, 2 Stat. 19 (repealed 1803).

${ }^{65}$ See Act of Dec. 19, 1803, ch. 6, 2 Stat. at 248.
} 
passed a second bankruptcy act that remained in effect until $1843 .{ }^{65}$ The 1841 law afforded a discharge to "every bankrupt" who surrendered all of his or her property. ${ }^{67}$ In order to prevent and penalize bankruptcy fraud, the statute provided that debtors would lose their right to a discharge for "wilful concealment" of property or "misstatement of accounts." ${ }^{18}$ The law also imposed criminal sanctions for perjury in connection with a bankruptcy case. ${ }^{69}$

During the two years that the 1841 Act remained in effect, a large number of debtors declared bankruptcy. ${ }^{70}$ Some of these debtors attempted to commit fraud, and at least one reported case specifically addressed the reliance argument. In United States $v$. Conner, ${ }^{71}$ a jury convicted a debtor of perjury after he failed to list on his bankruptcy schedules his interests in a house and a grocery store. The defendant challenged the conviction, arguing that he had relied on the advice of counsel. The court granted a new trial to allow a jury to consider the argument. It explained:

A bankrupt is bound to exhibit a true schedule of all his property, and if he fail to do this, wilfully and fraudulently, he is guilty of perjury. But if he, being unacquainted with the requirements of the law, shall be advised by his counsel, after the facts have been fully stated to him, that certain items of property are not required to be stated on his schedule, and he omits them, he is not guilty of perjury. He acts fairly in submitting the facts to his counsel, and, by acting under his advice, he shows a desire to conform to the law. ${ }^{72}$

This reasoning accords with the traditional analysis of the advice of counsel argument discussed in Part II. Instead of making reliance an independent defense, the court in Conner recognized that reliance could help the defendant by showing that he did not have an improper intent. Other cases under the $1841 \mathrm{Act}$, including one by Justice Joseph Story, exhibited a similar understanding of the law. ${ }^{73}$

${ }^{6}$ See Act of Aug. 19, 1841, ch. 9, 5 Stat. 440 (repealed 1843).

${ }^{67} I d . \$ 4,5$ Stat. at 443 .

${ }^{68}$ The discharge provisions stated more fully:

[I] fany such bankrupt shall be guilty of any fraud or wilful concealment of his property or rights of property, or shall have preferred any of his creditors contrary to the provisions of this act, or shall willfully omit or refuse to comply with any orders or direction of such court, or to conform to any other requisites of this act, or shall in the proceedings under this act, admit a false or fictitious debt against his estate, he shall not be entitled to any such discharge....

Id. $\S 4,5$ Stat. at $443-44$.

${ }^{69} I d$. $\$ 4,5$ Stat. at 444 .

${ }^{70}$ See Vern Countryman, A History of American Bankruptcy Law, 81 CoM. L.J. 226, 229 (1976) (estimating the number of bankruptcy filings during this period to be over 30,000 ).

${ }^{7} 25$ F. Cas. 595 (C.C.D. Mich. 1845) (No. 14,847).

${ }^{72} \mathrm{Id}$. at 595 .

${ }^{73}$ See In re Tebbetts, 23 F. Cas. 826(C.C.D.Mass. 1842)(No. 13,817)(Story,J.)(refusing to deny a discharge for omitting property from schedules when debtor had not understood the law); see also United States v. Nihols, 27F. Cas. 151 (C.C.D. Mich. 1845) (No. 15,880) (involving debtor who failed to list assets in reliance on advice of counsel); In re Wilson, 30 F. Cas. 97(D.C.D. Mass. 1843) (No. 17,783) (noting that a mistake may excuse an otherwise improper concealment of assets). 
Congress enacted a third bankruptcy statute in $1867 .{ }^{74}$ This law also granted debtors a discharge. But in a manner similar to the 1841 Act, the 1867 law denied relief to any bankrupt who had "wilfully sworn falsely" on a "petition, schedule, or inventory," or who had "given any fraudulent payment, gift, transfer, conveyance, or assignment of ... his property," or who had committed any one of seven other enumerated kinds of fraud. ${ }^{75}$

The 1867 law generated many reported decisions. One of the cases, In re Finn, ${ }^{76}$ addressed the reliance argument. On the eve of bankruptcy, the debtor gave two creditors a chattel mortgage to secure a previously unsecured debt. He also "sold" the twocreditors $\$ 1,010$ worth of goods without receiving the full amount in cash. When other creditors challenged these transactions as fraudulent conveyances, the debtor asserted that he was following his lawyer's instructions.

The court in Finn rejected the reliance argument as unsupported by the facts. It found that the debtor knew the wrongfulness of the transfers, "with or without professional advice" and, accordingly, denied the debtor a discharge..$^{77}$ The court's reasoningechoed the ideas stated in United Statesv. Conner and in Part II above. The court understood that reliance on advice of counsel could not alone excuse a debtor from liability. As a result, it focused on how the advice affected what the debtor was thinking when he committed the improper acts. ${ }^{78}$

After the repeal of the 1867 law in $1878,{ }^{79}$ the United States went without a bankruptcy law until Congressenacted the Bankruptcy Act of $1898 .^{80}$ The 1898 Act criminalized eight forms of bankruptcy fraud, including making false oaths or accounts. ${ }^{81}$ Although it provided that debtors ordinarily could receive a discharge, the 1898 Act prohibited discharging any debtor who: (1) had committed one of the eight criminal bankruptcy offenses, ${ }^{82}$ or (2) had "with fraudulent intent to conceal his true financial condition and in contemplation of bankruptcy, destroyed, concealed or failed to keep books of account or records from which his true condition might be ascertained." ${ }^{83}$ In 1903, Congress added four more exceptions, including one for debtors who had "transferred, removed, destroyed or concealed any ... property with intent to hinder, delay or defraud ... creditors." ${ }^{\text {"84 }}$

Debtors accused of bankruptcy fraud under the 1898 Act also asserted the reliance argument. In one of the earliest cases, In re Berner, ${ }^{85}$ a debtor failed to indicate

${ }^{74}$ See Act of Mar. 3, 1867, ch. 176, 14 Stat. 517 (repealed 1878).

75Id. § 29, 14 Stat. at 531-32.

${ }^{76} 9$ F. Cas. 72 (D.C.E.D. Mich. 1873) (No. 4,795).

TId. at 72.

${ }^{78} I d$. ("As to the statement that [the debtor] acted on the advice of counsel, it is sufficient to observe that it is not made to appear that he did so in good faith, believing that he had a legal right to do what he did ....").

${ }^{7}$ See Act of June 7, 1878, 20 Stat. 99 (1878).

${ }^{80}$ Act of July 1, 1898, ch. 541, 30 Stat. 544 (1898).

${ }^{81}$ See id. $\$ 29,30$ Stat. at 554 .

${ }^{82}$ See id. $\$ 14 b(1), 30$ Stat. at 550.

${ }^{83} I d$. $\$ 14 \mathrm{~b}(2), 30$ Stat. at 550.

84Act of Feb. 5, 1903, Pub. L. No. 57-62, ch. 487, § 4, 32 Stat. 797-798 (1903).

${ }^{83} 4$ Am. Bankr. Reps. 383 (circa 1900). 
on his bankruptcy schedules that he owned a life insurance policy and a small business. When creditors charged him with fraudulent concealment of assets, the debtor explained that he did not list the property because his attorney had told him that it had no value and that he did not have to list it. The court accepted the argument and granted the debtor a discharge. ${ }^{86}$

The Berner court, like the courts in Conner and Finn, again treated the reliance argument in the same manner as the non-bankruptcy cases. Rather than as a separate defense, the Berner court saw the debtor's reliance on advice of counsel merely as evidence for concluding that the debtor did not have a fraudulent intent. The court explained:

When a bankrupt has fully and fairly laid the facts as to a certain right he possesses before his attorneys, and receives the advice that it is not such an asset as is properly to be scheduled in bankruptcy, such advice of counsel is held to be evidence tending to deprive a false oath of its elements of wilfulness and fraud ... ${ }^{87}$

The Bemer court cautioned, however, that the reliance argument would not work in circumstances in which debtors do not actually rely on what a lawyer tells them. ${ }^{88}$

The Bankruptcy Act of 1898 remained in effect until Congress enacted the Bankruptcy Code of 1978, which remains in effect today. ${ }^{89}$ During this 80 -year period prior to the Code, the cases considering the reliance argument gradually diverged into two categories. One category of cases under the 1898 Act consistently adhered to the traditional view as illustrated in Bemer. ${ }^{90}$ As late as 1962, for example, the Ninth Circuit in Bisnov. United States ${ }^{91}$ reiterated the view that " [a]dvice of counsel is not regarded as a separate defense but rather as a circumstance indicating good faith which the trier of fact is entitled to consider on the issue of fraudulent intent. ${ }^{\text {m92 }}$

\footnotetext{
${ }^{86}$ The case has a rather colorful set of facts. For example, among other suspicious acts, the debtor and his wife snuck off from Ohio to New York with a trunk full of cash which they deposited in a bank in the name of the debtor's sister-in-law. The court observed that these facts spoke "loudly of fraud, intentional fraud, on the bankrupt's part," but did not warrant a denial of discharge under the statute. Id. at 402 .

${ }^{87}$ Id. at 396 (citing United States v. Conner, 25 F. Cas. 595 (C.C.D. Mich. 1845) (No. 14,847)).

${ }^{88} \mathrm{As}$ an example, the court suggested that if a debtor sought advice from an attorney that he knew had previously given erroneous advice, "it [would] hardly be considered that his real intent has been bona fide." Id. at 397.

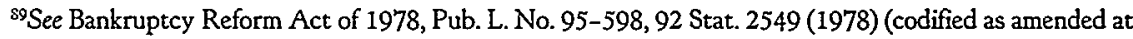
11 U.S.C. $\S \S 101-1328$ (1988 and Supp. V. 1992)).

${ }^{9}$ Some cases adhering to the traditional view excused debtors. See, e.g., In re Topper, 229 F.2d 691, 69293 (3d Cir. 1956); Thompson v. Eck, 149 F.2d 631, 634 (2d. Cir. 1945); Jones v. Gertz, 121 F.2d 782, 784 (10th Cir. 1941); Hultman v. Tevis (In re Tevis), 82 F.2d 940, 941 (9th Cir. 1936); Dilworth v. Boothe, 69 F.2d 621, 623-24 (5th Cir. 1934); Hunter v. MacFarlane (In re MacFarlane), 45 F.2d 994, 995 (9th Cir. 1930); Klein v. Powell, 174 F. 640, 642 (3d Cir. 1909); In re Van Meter, 208 F. Supp. 835, 836 (S.D. Cal. 1962); In re Soroko, 34 F. Supp. 825, 826 (S.D.N.Y. 1940). Other cases did not excuse debtors because they found the reliance argument unsupported by the facts. See, e.g , In re Mascolo, 505 F.2d 274, 276-77 (1st Cir. 1974); In re Breitling, 133 F. 146, 148-49 (7th Cir. 1904); Bisno v. United States, 299 F.2d 711, 719 (9th Cir. 1961), cert. denied, 370 U.S. 952 (1962); Stephens v. Stinson, 292 F.2d 838, 838 (9th Cir. 1961) (per curiam).

${ }^{91} 299$ F.2d 711 .

${ }^{92}$ Id. at 719.
} 
The other category of cases under the 1898 Act, however, analyzed the reliance argument in a different manner. Unlike the Berner, Finn, and Conner precedents, and unlike the non-bankruptcy decisions discussed in Part II, this second line of cases stopped looking at reliance on advice of counsel as merely one factor in determining the debtor's state of mind. Instead, these cases came close to transforming the argument into something akin to a common-law affirmative defense. Rather than focusing on how advice of counsel could affect the application of the statute, courts in the second category of cases developed on a case-by-case basis their own list of distinct elements that a debtor must show to avoid a denial of discharge.

In several instances, for example, courts held that a debtor could not receive a discharge because the debtor did not disclose all of the facts to the attorney providing the erroneous advice. ${ }^{93}$ Other courts rejected the argument because they found the debtor's reliance unreasonable. ${ }^{94}$ Still, other courts considered whether a debtor's action had caused any harm. ${ }^{95}$ None of these requirements finds explicit support in the language of the 1898 Act.

It is not clear why the courts found it necessary to develop a separate advice of counsel doctrine that included these additional elements. Two explanations seem possible. First, the courts may have thought that debtors were escaping punishment tooeasily. They may have felt that imposing additional requirements, like reasonableness and full disclosure, would limit the availability of a reliance argument. Second, the courts may have sought todevelop objective requirements upon which they could rule in order to avoid having to analyze a debtor's subjective intent. For example, regardless of whether a debtor actually believed an attorney's advice, the court could decide that reliance on the advice was unreasonable, and that therefore the defense should be rejected.

\section{Present Law}

At present, as noted above, three principal federal statutes punish consumer bankruptcy fraud. Section 727 of the Bankruptcy Code operates to deny discharges todebtors who have committed certain improper acts. Section 522 of the Bankruptcy Code deprives debtors of the right to claim exemptions in property that they voluntarily have transferred away or attempted to conceal. Section 152 of the Criminal Code, although rarely invoked, makes it a crime subject to a fine and imprisonment for debtors to commit the same general forms of misbehavior.

In recent years, hundreds of reported cases have considered requests to deny debtors a discharge under $\$ 727$. A smaller number of cases have discussed sanctions under $\S 152$ of the Criminal Code and $\S 522$ of the Bankruptcy Code. Despite all of this litigation, the status of the reliance argument under present law is not clear. In

\footnotetext{
${ }^{93}$ See, e.g., Remmers v.Merchants'-Laclede Nat'l Bank, 173 F. 484 (8th Cir. 1909); In re Breitling, 133 F. 146, 150 (7th Cir. 1904).

${ }^{94}$ See, e.g., Sinclair v. Butt (In re Sinclair), 284 F. 568, 570 (8th Cir. 1922).

${ }^{25}$ See, e.g., Friendly Fin. Discount Corp. v. Jones (In re Jones), 490 F.2d 452, 457 (5th Cir. 1974).
} 
fact, the rules regarding advice of counsel seem less settled now than under the previous bankruptcy laws.

\section{Courts of Appeals Decisions Interpreting $\$ 727(a)$}

Four published federal courts of appeals decisions have addressed in depth the reliance argument under $\S 727.96$ Two of the four decisions concern application of $\S 727$ (a)(4) to debtors charged with filing false schedules. In City National Bank $v$. Bateman (In re Bateman), ${ }^{97}$ an Eighth Circuit case decided in 1981, a debtor falsely answered two questions on his bankruptcy schedules regarding income that he had received and a gift that he had made. The court rejected the debtor's reliance argument, explaining that, "[For the reliance argument to succeed], reliance on counsel must be reasonable. Despite disclosure to counsel, a petitioner still must attest to the truth and completeness of answers given under oath. To exclude income and the gift from the bankruptcy petition under the circumstances was unreasonable." ${ }^{\text {ng }}$

In Boroff $v$. Tully (In re Tully), ${ }^{99}$ a First Circuit case decided in 1987, a debtor failed to indicate on his bankruptcy forms that he owned certain promissory notes and other assets. The debtor's counsel testified that he had advised the debtor to omit the information, but the court found the testimony irrelevant. The court stated: "It is well settled that reliance upon advice of counsel is, in this context, no defense where it should have been evident to the debtor that the assets ought to be listed in the schedules." 100

The two other circuit court cases address denials of discharge under $\S 727(\mathrm{a})(2)$ for transfers made by debtors with intent to hinder or defraud a creditor. In First Beverly Bank v. Adeeb (In re Adeeb), ${ }^{101}$ decided by the Ninth Circuit in 1986, the debtor transferred real property to some friends after consulting with an attorney. The court recognized that, upon a proper showing, the reliance argument may preclude the denial of discharge. It stated, "Generally, a debtor who acts in reliance on advice of his attorney lacks the intent required to deny him a discharge of his debts." 102

The court, however, ruled that the reliance argument did not avail the defendant on the particular facts of the case. It explained:

\footnotetext{
"In addition, the Ninth Circuit issued an unpublished opinion touching on the reliance argument and reached an unusual result. In Summers v. Rigby (In re Summers), No. 92-36968, 1994 WL 96365 (9th Cir. Mar. $24,1994)$, the court affirmed a summary judgment denying a debtor a discharge for transferring property in violation of $\$ 727(\mathrm{a})$ (4). Although the debtor raised the reliance argument, the court found no issues of material fact. See 1994 WL 96365 , at * 3 . This decision suggests that the court did not think that reliance on advice of counsel, even if proved, could excuse a debtor's misconduct.

${ }^{97} 646$ F.2d 1220 (8th Cir. 1981).

${ }^{98}$ Id. at 1220 (citation omitted).

${ }^{99} 818$ F.2d 106 (1st Cir. 1987).

${ }^{100} I$ d. at 111 (citations omitted).

${ }^{101} 787$ F.2d 1339 (9th Cir. 1986).

${ }^{102} I d$. at 1341 (citing Hultman v. Tevis, 82 F.2d 940, 941 (9th Cir. 1936)).
} 
In this case the bankruptcy court found that both [the lawyer and the debtor] ... "knew that the purpose of the transfers was to hinder or delay creditors of the debtor." Such a finding precludes the defense of good faith reliance on the advice of an attorney even if the client is otherwise innocent of any improper purpose. A debtor who knowingly acts to hinder or delay his creditors acts with the very intent penalized by section $727(\mathrm{a})(2)(\mathrm{A}){ }^{103}$

In Norwest Bank Nebraska v. Tveten (In re Tveten), ${ }^{104}$ another Eighth Circuit case decided in 1988 , a debtor attempted to transfer $\$ 700,000$ of nonexempt property into an exempt pension account immediately before bankruptcy. A creditor asked for a denial of discharge under $\$ 727$ (a)(2). Although the debtor had acted according to instructions from his counsel, the court rejected his reliance argument. Citing Bateman, the courtstated: "Tveten's reliance on his attorney'sadvice does not protect him here, since that protection applies only to the extent that the reliance was reasonable."

The preceding excerpts from the federal courts of appeals' decisions in Bateman, Tully, Adeeb, and Tveten give rise to four observations. First, the four cases conflict with each other in at least one way and, perhaps, two. Although Adeeb and Tveten agree that reliance on advice of counsel can excuse a fraudulent transfer of property, they disagree about the manner in which the debtor must rely. The court in Adeeb adopted a subjective standard, concluding that the debtor must rely in "good faith." ${ }^{106}$ By contrast, the court in Tveten adopted an objective standard, stating that the reliance must be "reasonable." 107

This difference could easily change the outcome of future cases. Under Adeeb, as long as a debtor honestly believes what a lawyer says, the debtor can rely on any advice given, even if peculiar or unreasonable. Under Tveten, by contrast, mere honest reliance will not suffice. A debtor can follow only the advice that an ordinary debtor would reasonably follow.

Tully and Bateman possibly disagree on a different issue--whether the reliance argument can help a debtor who faces a denial of discharge under $\$ 727(\mathrm{a})(2)$ for filing false bankruptcy schedules. The court in Bateman unequivocally stated that reliance on advice of counsel could excuse a debtor, provided that the reliance was "reasonable." ${ }^{108}$ In contrast, there are two ways to interpret the $\mathcal{T}$ ully court's terse statement that reliance on advice of counsel "is, in this context, no defense where it should be evident to the debtor that the assets ought to be listed." 109

\footnotetext{
${ }^{103} I d$. at 1343 .

${ }^{104} 848$ F.2d 871 (8th Cir. 1988).

${ }^{105}$ Id. at 876 (citing City Nat'l Bank v. Bateman (In re Bateman), 646 F.2d 1220, 1224 (8th Cir. 1981)).

${ }^{105}$ Adeeb, 787 F.2d at 1341.

${ }^{107}$ Tveten, 848 F.2d at 876.

${ }^{10}$ City Nat'l Bank v. Bateman (In re Bateman), 646 F.2d 1220, 1224 (8th Cir. 1981).

${ }^{109}$ Boroff v. Tully (In re Tully), 818 F.2d 106, 111 (1st Cir. 1987).
} 
On one hand, the Tully court might be adopting the same standard as Bateman using different words. By saying that "it should have been evident" that the debtor's assets "ought to be listed," perhaps the court means that the debtor could not receive a discharge because his reliance was not reasonable. If this interpretation is correct, then the court by implication would presumably allow debtors to use the reliance argument when their reliance is reasonable.

On the other hand, the Tully court might be saying that the reliance argument never excuses a failure to list assets under $\$ 727(\mathrm{a})(2)$. With the phrase "in this context," the court might be trying to single out $\$ 727(\mathrm{a})(2)$ as a provision for which the reliance argument does not work. Several lower courts have adopted this interpretation of the law. ${ }^{110}$ If this interpretation is correct, then Tully differs from Bateman.

Second, the circuit courts decided these cases without addressing the language of the Bankruptcy Code. Of the four cases, only Adeeb mentions $\$ 727$ when discussing the reliance argument, and does so only as an afterthought, having already stated its conclusion. Instead of focusing on the language of the Bankruptcy Code, Tully, Bateman, and Adeeb rest principally on old precedents under the Bankruptcy Act of $1898 .{ }^{111}$ Tveten, meanwhile, merely cites Bateman.

Third, perhaps because the federal courts of appeals have not focused on the language of $\$ 727(\mathrm{a})$, they appear to have overlooked the various distinctions among the exceptions set forth in the different paragraphs. Although the First Circuit in Tullymay have been trying to establish a rule unique to $\$ 727(\mathrm{a})(2)$, neither of the other circuits did anything comparable. In fact, the Eighth Circuit considered \$727(a)(4) in Bateman and $\S 727(\mathrm{a})(2)$ in Tveten, but drew no distinction between them. Instead, the court based its holding in Tveten solely on the Bateman precedent.

Fourth, the cases seem to have abandoned the traditional view that advice of counsel is not an affirmative defense. Unlike Bemer, Bisno, and other decisions under the 1898 Act, none of these four decisions explained that reliance on advice of counsel constituted only evidence of the debtor's intent.Infact, only Adeebseemed concerned about the debtor's state of mind. By requiring specific showings like reasonableness, the courts seem to have created a doctrine with requirements not derived from anything expressed in $\S 727$, nor particularly related to the debtor's state of mind.

\section{Lower Court Interpretations of $\$ 727$}

The decisions of many federal district and bankruptcy courts resemble Tully, Adeeb,Bateman, and Tveten. Just like the federal courts of appeals, some lower courts

\footnotetext{
${ }^{110}$ See, eg., Holland v. Sausser (In re Sausser), 159 B.R. 352, 356 (Bankr. M.D. Fla. 1993); Morton v. Dreyer (In re Dreyer), 127 B.R. 587, 597 (Bankr. N.D. Tex. 1991) (holding that the reliance argument will not excuse the filing of false forms).

${ }^{111}$ As indicated in the quotations above, Bateman relies on Stephens v. Stinson, 292 F.2d 838 (9th Cir. 1961) (per curium). Tully relies on In re Mascolo, 505 F.2d 274, 277 (1st Cir. 1974) and In re Russell, 52 F.2d 749,754 (D.N.H. 1931). Adeeb relies on Hultman v. Tevis, 82 F.2d 940, 941 (9th Cir. 1936).
} 
disagree as to whether debtors who have made false oaths may use the reliance argument ${ }^{112}$ and as to whether debtors must rely in a reasonable manner. ${ }^{113}$

Unlike the federal courts of appeals, however, some lower courts have looked closely at the language of $\S 727$ and have not simply relied on old Bankruptcy Act precedents. As a result, these courts have taken better notice of the nuances in $\$ 727$, and have tended to retain the traditional perspective that the reliance argument does not constitute a separate defense.

Aetna Insurance Co. v. Nazarian (In re Nazarian) ${ }^{114}$ provides a good example. In that case, the debtor failed to list property on schedules filed with the court. In applying $\S 727(a)(4)$, the court explained: "Because a debtor is unlikely to testify directly that his intent was fraudulent, the courts may deduce fraudulent intent from all the facts and circumstances of a case." ${ }^{115}$ The court then explained that, depending on the facts, "advice of counsel may ... negate the inference of fraudulent intent."116 The court thus determined what the language of the statute required and explained how advice of counsel could bear on that requirement. Other cases have done the same in analyzing different paragraphs of $\S 727 . .^{117}$

\section{Cases Interpreting $\S 152$ and $\S 522$}

The status of the reliance argument under $\$ 152$ of the Criminal Code and $\S 522$ of the Bankruptcy Code is unclear. Because of the paucity of criminal cases brought for bankruptcy fraud, the circuit courts have said almost nothing on the issue. A few rather old cases excused debtors under a prior version of $\S 152$ on the basis of the reliance argument. ${ }^{118}$ In recent years, however, the few courts that have addressed the provision each have done little more than cursorily uphold jury instructions given by trial courts in criminal prosecutions. ${ }^{119}$ The author has found no cases on the question

${ }^{112}$ Compare, e.g., Holland v. Sausser (In re Sausser), 159 B.R. 352, 356 (Bankr. M.D. Fla. 1993); Morton v. Dreyer (In re Dreyer), 127 B.R. 587, 597 (Bankr. N.D. Tex. 1991) (holding that the reliance argument cannot excuse filing of false forms) with American State Bank v. Montgomery (In re Montgomery), 86 B.R. 948, 958 (Bankr. N.D. Ind. 1988); Aetna Ins. Co. v. Nazarian (In re Nazarian), 18 B.R. 143, 147 (Bankr. D. Md. 1982) (holding that the argument will excuse debtor in proper circumstances).

${ }^{113}$ See. e.g., Federal Land Bank v. Ellingson (In re Ellingson), 63 B.R. 271, 277 (Bankr. N.D. Iowa 1986); American Sav. \& Loan Ass'n v. Weber (In re Weber), 99 B.R. 1001, 1018 (Bankr. D. Utah 1989) (requiring reasonableness); but see Peoples State Bank v. Drenckhahn(In re Drenckhahn), 77 B.R.697,707(Bankr. D.Minn. 1987); Aetna Ins. Co. v. Nazarian (In re Nazarian), 18 B.R. 143, 147 (Bankr. D. Md. 1982) (not requiring reasonableness).

${ }^{11} 18$ B.R. 143 (Bankr. D. Md. 1982).

i1sId. at 146 .

116 Id. at 147.

"17Harkins v. Patterson (In re Patterson), 70 B.R. 124 (Bankr. W.D. Mo. 1986), provides another example. In that case, a bankruptcy court accepted a reliance argument from a debtor who had failed to list an asset on his schedules. Reflecting the language of $\$ 727(\mathrm{a})(2)$, the court found that the defendant did not have an "actual and subjective fraudulent intent. ${ }^{n}$ Id. at 128 . The court added that "advice of counsel is a factor to be considered" when deciding what intent the debtor had. Id. at $128 \mathrm{n} .9$.

${ }^{118}$ See, e.g., Levinson v. United States, 263 F. 257 (3d Cir. 1920).

${ }^{119}$ See United States v. West, 22 F.3d 586, 598 \& n.36 (5th Cir.), cert. denied, 115 S. Ct. 584 (1994); United States v. Wilkins, No. 88-1320, 1989 WL 79802 (9th Cir. July 11, 1989) (unpublished opinion). 
whether a debtor may use the reliance argument to escape a denial of the right to claim exemptions under $\S 522(\mathrm{~g})(1){ }^{120}$

\section{HOW COURTS SHOULD TREAT THE RELIANCE ARGUMENT UNDER EXISTING STATUTES}

Most federal courts of appeals have not yet determined what effect to give the reliance argument under $\$ \S 727$ and 522 of the Bankruptcy Code or $\S 152$ of the Criminal Code. These courts will have to choose among the different approaches described in Part III. The following discussion makes specific recommendations about how the courts should interpret these statutes as they currently exist.

Section $A$ argues that in bankruptcy cases courts should adopt the traditional approach towards the reliance argument. Specifically, courts should scrutinize the requirements of particular offenses to determine whether evidence of reliance on advice of counsel might negate a finding of any elements. Sections $B$ and $C$ then show in detail how this approach works, specifying exactly what effect reliance on advice of counsel should have on each pertinent section of the Bankruptcy and Criminal Codes.

\section{A. STATUTORY INTERPRETATION}

The Bankruptcy Code and the Criminal Code establish a variety of bankruptcy wrongs or offenses. Neither statute, however, says anything explicitly about reliance on advice of counsel. As noted in Part III, the courts have dealt with this problem in two ways. Courts adopting the traditional approach have concluded that evidence of reliance may negate certain elements of the prohibited actions, but that reliance on advice of counsel is not an affirmative defense. Other courts have tried to make reliance on advice of counsel into something akin to an affirmative defense, determining the specific requirements of the defense in a case-by-case manner without reference to the language of the pertinent statutes.

The author recommends that courts should follow the traditional approach. Even if courts conclude that as a matter of policy debtors should have to demonstrate certain requirements to use the reliance argument, such as reasonableness or full disclosure, they have no clear authority to impose these requirements without explicit statutory support. On the contrary, the Supreme Court has specifically rejected attempts by courts to read requirements into the Bankruptcy Code. ${ }^{121}$

The former approach accords with the historical approach in non-bankruptcy and bankruptcy cases. Courts outside of bankruptcy generally agreed, and still do,

\footnotetext{
${ }^{120}$ In one case, In re Snyder, 66 B.R. 886 (Bankr.D. Mass. 1986), a debtor transferred real property in violation of the Bankruptcy Code. The court noted in its statement of facts the debtor had acted at the advice of counsel. See id. at 889 . The court, however, did not discuss the advice of counsel when it concluded that the debtor had lost his right to claim an exemption under $\$ 522(\mathrm{~g})(1)$. See id. at 894.

${ }^{121}$ See, e.g, Taylor v. Freeland \& Kronz, 112 S. Ct. 1644, 1648-49 (1992) (refusing to read into $\$ 522(1)$ of the Bankruptcy Code a requirement of "good faith").
} 
that reliance on advice of counsel is not an affirmative defense to crimes or torts. Until the mid-part of this century, courts within the bankruptcy context held this same view. More recently, however, some bankruptcy cases have departed from this traditional approach and have failed to articulate a good reason for doing so. Moreover, these latter cases for the most part have failed to recognize that this view differs from the traditional approach.

The discussion that follows shows that by parsing the pertinent sections of the Bankruptcy and Criminal Codes, courts can determine the proper treatment of the reliance argument. The discussion interprets the statutes literally, without referring to legislative history or general policy arguments. Courts should do the same for two reasons. First, the Supreme Court in recent years has interpreted the Bankruptcy Code as literally as possible. ${ }^{122}$ Second, the statutory language at issue does not contain any significant ambiguities. Courts that have consulted the statute have not disagreed about what it means.

Tosay that the courts should interpret the governingstatutes to mean what they say is not to suggest that the statutes rest on good policy or that they could not be improved. However, policy considerations are left for the discussion in Part $V$ below, which describes how Congress might enact new legislation to remedy deficiencies in the existing laws.

\section{B. The Reliance Argument Under $\$ 727$ OF the Bankruptcy Code}

As previously discussed, the Bankruptcy Code addresses different forms of bankruptcy fraud in paragraphs (a)(2) through (a)(5) of $\$ 727$. A close examination of the language of these paragraphs reveals that each mandates a different treatment of the reliance argument. As a result, courts should consider each of the paragraphs separately when a debtor asserts a reliance argument.

Section $727(\mathrm{a})(2)$ principally prohibits a court from granting the debtor a discharge if the debtor has transferred or concealed property "with intent to hinder, delay, or defraud" a creditor or trustee. ${ }^{223}$ The word "intent" generally refers to a "state of mind in which a person seeks to accomplish a given result through a course of action. ${ }^{\text {"24 }}$ Accordingly, a court should deny a discharge under paragraph (a)(2)only if the debtor is consciously trying todelay, hinder, or defraud a creditor.Adebtor lacks the requisite intent if the debtor does not want to delay, hinder, or defraud a creditor

\footnotetext{
${ }^{122}$ See generally Lowell P. Bottrell, The Supreme Court and the "Plain Meaning" of the Bankruptcy Code: A Review of Recent and Pending Supreme Court Decisions, 69 N.D. L. Rev. 155 (1993); Bruce A. Markell, Conspiracy, Literalism, and Ennui at the Supreme Court: An Examination of Bankruptcy Cases decided from 1990 to 1993,41 FED. B. News \&J. 174 (1994); Robert K. Rasmussen, A Study of the Costs and Benefits of Textualism: The Supreme Court's Bankruptcy Cases, 71 WASH. U. L.Q. 535 (1993).

${ }^{123} 11$ U.S.C. $\$ 727(\mathrm{a})(2)$ (1988). For the complete text of this provision, see supra note 23.

12'Black's Law Dictionary 810 (6th ed. 1990). For similar definitions, see Wagner v. Pro, 603 F.2d 1005, 1010 (D.C. Cir. 1979); Restatement (Second) of Torts $\$ 8 A$ (1977); W. Page Keeton et AL., Prosser and KeETON ON THE LAW OF TORTS $\$ 8$, at 31 (1971).
} 
even if the debtor takes actions that do just that. ${ }^{125}$

Evidence of advice of counsel is relevant under paragraph (a)(2) because it may show that the debtor did not act with the requisite intent. For example, suppose that a debtor transfers property after filing a bankruptcy petition. At trial, the issue will arise whether the debtor acted with a prohibited specific intent. Part of the evidence might be what legal advice the debtor had. If a lawyer told a debtor that the transfer would not harm any creditors, and the debtor believed the lawyer, a court could conclude (unless stronger evidence showed something to the contrary) that the debtor did not act with an intent to delay, hinder, or defraud. The court would then have no basis to deny a discharge under paragraph (a)(2).

If the debtor did not believe the lawyer's advice, the result would change. For example, suppose the debtor consciously wanted to impede collection efforts and asked an unscrupulous lawyer to rubber-stamp a course of action that the debtor knew would violate the law. In that case, as several courts have observed, the debtor could have had the intent to hinder, delay, and defraud notwithstanding the lawyer's advice. ${ }^{126}$

Inexamining the debtor'sintent for the purpose of paragraph(a)(2),courts should not insist on reasonableness. Suppose, for example, that on the day before filing bankruptcy, after consulting a lawyer, a debtor gives away all of the property that would otherwise become property of the bankruptcy estate. Most people would realize that such an action would defraud creditors. In fact, a court might infer from the circumstances that the debtor had an intent to defraud. Yet, if the evidence as a whole shows that the debtor did not actually have that intent, then paragraph (a)(2) would not require denial of the discharge. Courts that have not required debtors to act reasonably to avoid a denial of discharge under paragraph(a)(2), including First Beverly Bank v. Adeeb (In re Adeeb), have correctly interpreted the statute in this respect. ${ }^{127}$ Courts that have required reasonableness, such as Norwest Bank $\mathcal{N}$ ebraska v. Tveten (In re Tveten), have misinterpreted it. ${ }^{128}$

Section $727(a)(3)$ has slightly different language. It says that a court may refuse to grant a discharge if a debtor has committed any one of a variety of misdeeds, including destroying, mutilating, or falsifying business records. ${ }^{129}$ The paragraph does not require the debtor to have acted with any specific intent, but it does contain a final

\footnotetext{
${ }^{125}$ For an example of a court that correctly has understood this point, see Peoples State Bank v. Drenckhahn (In re Drenckhahn), 77 B.R. 697, 706-07(Bankr. D. Minn. 1987) (granting discharge because debtor did not act with actual intent to hinder, delay or defraud creditors).

${ }^{126}$ Several courts have rejected the reliance argument where the debtor knew the wrongfulness of a transfer under $\$ 727(\mathrm{a})$ (2) despite professional advice to the contrary. See, e.g., First Beverly Bank v. Adeeb(In re Adeeb), 787 F.2d 1339, 1343 (9th Cir. 1986); Creative Recreational Sys. v. Rice (In re Rice), 109 B.R. 405, 405 (Bankr. E.D. Cal. 1989), aff 'd, 126 B.R. 822 (Bankr. 9th Cir. 1991). These courts state that the debtor did not rely "in good faith," when they in fact mean that the debtor did not rely at all.

${ }^{127}$ See, e.g., Adeeb, 787 F.2d at 1343; Rice, 109 B.R. at 405; Drenckhahn, 77 B.R. at 707.

${ }^{128}$ See, e g., Norwest Bank Nebraska v. Tveten (In re Tveten), 848 F.2d 871, 876 (8th Cir. 1988); American Sav. \& Loan Ass'n v. Weber (In re Weber), 99 B.R. 1001, 1018 (Bankr. D. Utah 1989).

${ }^{129} 11$ U.S.C. $\$ 727(\mathrm{a})(3)$ (1988). For the complete text of this provision, see supra note 25.
} 
clause excusing debtors whose actions are "justified under all of the circumstances of the case." ${ }^{\text {130 }}$

Courts should interpret the final clause of paragraph (a)(3) to open the door to reliance arguments. Suppose, for example, that a debtor destroys some accounting materials prior to filing a bankruptcy petition. Whether it is appropriate to deny the debtor's dischargedependsonall the circumstances. One factor to consider is whether the debtor's lawyer advised the debtor to destroy the books. ${ }^{131}$

Paragraph (a)(3) differs from paragraph (a)(2) in an important respect. Under paragraph (a)(2), the reasonableness of the debtor's actions is not by itself conclusive when the court is trying to determine whether the debtor had an intent to defraud. Yet, the language of paragraph (a)(3) would seem to require the court to consider the reasonableness of the debtor's actions in determining whether to withhold a discharge because it is one of the "circumstances of the case." ${ }^{\text {"132 }}$

Section $727(a)(4)$ denies a discharge to a debtor who has "knowingly and fraudulently" made a false oath or account, or has engaged in other related misbehavior. ${ }^{133}$ Debtors may violate this provision when they file schedules that do not list all of the property they own. Debtors inclined to commit fraud may omit assets in the hope that the trustee will not discover them and distribute them to creditors.

Some courts, apparently including Boroff $v$. Tully (In re Tully), have held that advice of counsel cannot excuse the filing of a false schedule. ${ }^{134}$ Scrutiny of the statute, however, compels a different conclusion. According to standard definitions, a person acts "knowingly" when he or she acts "with an awareness of the nature of his conduct."135 A person acts "fraudulently" when the person acts with an intent to deceive. ${ }^{136}$ Advice of counsel may affect the factual findings with respect to each of these elements.

The requirement under paragraph (a)(4) that the debtor act "knowingly" may prevent a denial of discharge in certain cases. For example, suppose that a lawyer tells a debtor that certain property does not have to be listed as an asset because, in the lawyer's opinion, the debtor does not have a valid property interest in it. If the debtor

\footnotetext{
"soId.

${ }^{131}$ See, e.g., Harkins v. Patterson (In te Patterson), 70 B.R. 124, 127 n.1, 128 n.9 (Bankr. W.D. Mo. 1986) (holding that advice of counsel is a factor to be considered); Ford v. Mellon Fin. Serv. (In re Ford), No. Civ. H85-3551, 1986 WL 14997, at *4 (Bankr. S.D. Tex. Dec. 19, 1986) (recognizing advice of counsel as an excuse, but refusing to allow debtor to raise the issue because he did not raise it in the bankruptcy court).

${ }^{132}$ One bankruptcy court, at least implicitly, has reached this conclusion. See Patterson, 70 B.R. at $127 \mathrm{n} .1$ \& $128 \mathrm{n} .9$ (considering both "advice of counsel" and what debtor "should know").

${ }^{133} 11$ U.S.C. $\$ 727($ a)(4) (1988). For the complete text of this provision, see supra note 24.

${ }^{134}$ See, e.g., Boroff v. Tully (In re Tully), 818 F.2d 106 (1st Cir. 1987); Holland v. Sausser (In re Sausser), 159 B.R. 352, 356 (Bankr. M.D. Fla. 1993); Morton v. Dreyer (In re Dreyer), 127 B.R. 587, 597 (Bankr. N.D. Tex. 1991); Villas on the Green, Inc. v. Trauger (In re Trauger), 101 B.R. 378, 382 (Bankr. S.D. Fla. 1989).

${ }^{13}$ B'BLACK's Law DictionaRY 872 (6thed. 1990). See United Statesv. Baily, 444 U.S. 394, 404(1980); United States v. United States Gypsum Co., 438 U.S. 422, 445 (1978); State v. Kroll, 682 S.W.2d 78, 81 (Mo. Ct. App. 1984) (providing similar definitions).

${ }^{136}$ BLACK's Law DictionaRy 662 (6th ed. 1990). Accord Reilly v. Pinkus, 338 U.S. 269, 276 (1949); Seven Cases v. United States, 239 U.S. 510, 517 (1916).
} 
actually believes the lawyer, then the debtor would not be aware of the falsity in the schedules. The reliance argument should prevent a denial of discharge under paragraph (a)(4) because the debtor did not "knowingly" make a false statement.

A federal district court in In re Soroko, ${ }^{137}$ a case decided under the Bankruptcy Act, explained this point:

Ignorance of the law on the part of the bankrupt and his attorney may lead the attorney to advise his client without a knowledge of relevant information in the possession of the client. This may result in the bankrupt's statements under oath being false, but it does not render the statements intentionally false. ${ }^{138}$

This reasoning would seem valid in interpreting paragraph (a)(4) of the Bankruptcy Code.

Advice of counsel, however, should not always prevent the denial of the discharge under paragraph (a)(4). Suppose, for example, that the debtor owns some property, like corporate stock, and knows that the ownership is valid. Supposefurther that a lawyer incorrectly tells the debtor that he does not have to list corporate stock as an asset, even though the schedule requires the debtor to list all assets. If the debtor does not list the asset, the debtor is "knowingly" filing a false schedule, regardless of the lawyer's advice. In such circumstances, courts generally may infer an "intent to deceive" and may thus find that the debtor also acted fraudulently. ${ }^{139}$

Courts, however, should not hold debtors to a standard of reasonableness under paragraph (a)(4). The section states that courts should deprive debtors of their discharge when they know they are filing false statements, not when they merely should know. Accordingly, courts that have insisted on reasonableness under paragraph (a)(4), including City National Bank v. Bateman (In re Bateman), have arguably misinterpreted the Bankruptcy Code. ${ }^{140}$

One caveat deserves mention on this point. Even if the law does not require reasonableness, the debtor's credibility may become an issue. When a debtor testifies to not knowing something that any reasonable debtor would have known, the court may decide that the debtor is not telling the truth. The court might infer that the

\footnotetext{
${ }_{137} 34$ F. Supp. 825 (S.D.N.Y. 1940).

${ }^{138}$ Id. at 826. A few courts have correctly followed this approach under the Bankruptcy Code. See, e.g., Aetna Ins. Co. v. Nazarian (In re Nazarian), 18 B.R. 143, 147 (Bankr. D. Md. 1982).

${ }^{139}$ Various courts have rejected the reliance argument after concluding that the debtor knew the falsity of information included on a statement even without professional advice. See, e.g., Barnett Bank v. Muscatell (In re Muscatell), 113 B.R. 72, 75 (Bankr. M.D. Fla. 1990); American State Bank v. Montgomery (In re Montgomery), 86 B.R. 948, 958 (Bankr. N.D. Ind. 1988); Butler v. Ingle (In re Ingle), 70 B.R. 979, 984 (Bankr. E.D.N.C. 1987); Day v. Ailetcher (In re Ailetcher), 49 B.R. 681, 685 (Bankr. D. Haw. 1985).

${ }^{1+0}$ See, e.g., City Nat'l Bank v. Bateman (In re Bateman), 646 F.2d 1220 (8th Cir. 1981);Montgomery, 86 B.R. at 958; Federal Land Bank v. Ellingson (In re Ellingson), 63 B.R.271,277(Bankr.N.D. Iowa 1986). See also Boroff v. Tully (In re Tully), 818 F.2d 106, 111 (1st Cir. 1987) (holding defense not available when it should have been evident).
} 
debtor actually did know the falsity of the statements. ${ }^{141}$

Section $727(\mathrm{a})(5)$, the final provision of $\$ 727$ addressing consumer bankruptcy fraud, provides for the denial of the discharge if the debtor fails "to explain satisfactorily ... any loss of assets or deficiency of assets to meet the debtor's liabilities."142 This section addresses cases in which the debtor admits to owning an asset, such as a sum of cash or some valuable property, but the debtor gives a suspicious or incomplete story about what has happened to it. Without this prohibition, debtors could list assets on their schedules, but still prevent trustees from having access to them. For example, a debtor might indicate ownership of corporate stock certificates or cash on schedules filed in court, but assert that the whereabouts of the certificates or cash are unknown. ${ }^{143}$

The reliance argument should not excuse violations of paragraph (a)(5) because the paragraph does not require the debtor to have a specific intent or any particular knowledge. Instead, the paragraph requires the debtor only "to explain." 144 If the debtor does not provide a satisfactory explanation, the court cannot grant a discharge. Whether a lawyer told the debtor not to provide an explanation, or that a particular explanation should suffice, appears to make no difference under the language of $\$ 727$. If the debtor tells the trustee that his car is gone and he does not know what happened to it, the court might find that statement unsatisfactory regardless of any advice that the debtor had received. ${ }^{145}$

The foregoing discussion describes the circumstances in which a debtor may use the reliance argument under $\$ 727$ of the Bankruptcy Code. Courts should not attempt to expand the argument by creating a general reliance on counsel defense. Such a general defense finds no support in the statutory language. It also would run contrary to a century of decisions both inside and outside the bankruptcy context.

Further, courts should not impose reasonableness requirements on debtors arguing reliance if reasonableness is not required by the Bankruptcy Code. Regardless of how courts view the merits of the present law, debtors should not lose their discharges except in the instances mandated by Congress. As the statute is presently written, reliance on advice of counsel will sometimes help the debtor and other times will not.

\section{Reliance UNDER $§ 152$ OF THE CRIMnal CODE AND $§ 522$ OF THE} BANKRUPTCY CODE

Most cases involving the reliance argument have concerned $\S 727$ of the Bank-

\footnotetext{
${ }^{1 * 1}$ See, e.g., Raymos v. Collins (In re Collins), 19 B.R. 874, 877 (Bankr. M.D. Fla. 1982) (court did not believe debtor).

${ }^{142} 11$ U.S.C. $\$ 727(a)(5)$ (1988). For the relevant text of this provision, see supra note 26.

${ }^{14}$ See, e.g., Farouki v. Emirates Bank Int'l, Ltd., 14 F.3d 244, 251 (4th Cir. 1994) (failing to explain what happened to corporate stock owned by debtor); First Federated Life Ins. Co. v. Martin (In re Martin), 698 F.2d 883,886 (7th Cir. 1983) (failing to explain what happened to $\$ 15,000$ in cash).

${ }^{14} 11$ U.S.C. $\$ 727(\mathrm{a})(5)(1988)$.

${ }^{145} \mathrm{~A}$ few bankruptcy courts correctly have rejected advice of counsel as an excuse under $\$ 727(\mathrm{a})(5)$. See, e.g., Randolph v. Somerville (In re Somerville), 73 B.R. 826, 837 (Bankr. E.D. Pa. 1987); In re Taubman, No. 389-01642, 1991 WL 225982, at *5-6 (Bankr. S.D. Ohio Oet. 25, 1991).
} 
ruptcy Code. Courts in the future, however, may encounter the argument in cases under $\S 152$ of Criminal Code and $\S 522$ of the Bankruptcy Code. Courts should apply the same type of statutory analysis in these cases.

Section 152 establishes criminal penalties for nine different forms of consumer bankruptcy fraud. These include concealing assets, making false oaths, offering bribes, and other similar conduct. The statute, however, applies only to acts performed "knowingly and fraudulently." ${ }^{146}$ The reliance argument, as a result, may protect the debtor from criminal penalties if the evidence shows that the debtor did not act with the required mental state. The analysis, without repeating it here, would parallel the analysis under $\$ 727(\mathrm{a})(4)$ discussed above which also requires that the debtor act "knowingly and fraudulently."

Section 522(g)(1) of the Bankruptcy Code prohibits a debtor from claiming exemptions in property that the trustee recovered after "a voluntary transfer" by the debtor or after an attempt by the debtor to "conceal" it. ${ }^{147}$ Because the section does not state that the debtor has to have acted with any specific intent, evidence of reliance on advice of counsel generally should not matter. No cases at the time of this writing, however, have confirmed (or rejected) this view.

\section{HOW CONGRESS SHOULD REFORM THE CURRENT LAW}

The foregoing discussion demonstrated how courts should treat the reliance argument under current provisions of the Bankruptcy and Criminal Codes. Whether Congress should alter these provisions in any manner is a separate issue. Because Congress has been showing substantial interest in bankruptcy reform, ${ }^{148}$ this portion of the Article discusses the possibility of legislation to address the reliance on advice of counsel argument.

Twoconsiderations militate against significantly changing the present law. First, experience has largely validated the current standards. As indicated in Part III above, courts have applied essentially the same substantive prohibitions on bankruptcy fraud since the early 1800s. Although the wording of each of the five federal bankruptcy acts has differed somewhat, each of the acts has forbidden the same types of misconduct. Any radical change of the law might produce unexpected and undesirable results.

Second, not enough factual information exists to recommend any major reforms. The reported cases reveal that debtors caught transferring assets and lying on bankruptcy schedules may raise the reliance argument in an attempt to escape punishment. But exactly how many debtors invoke the argument and how many

\footnotetext{
${ }^{146} 18$ U.S.C. $\$ 152$ (1988). For the relevant text of this provision, see supra note 28.

${ }^{147} 11$ U.S.C. $\$ 522(\mathrm{~g})(1)$ (1988). For a discussion of this provision, see supra notes 34-36 \& accompanying text.

${ }^{148}$ Congress recently passed the Bankruptcy Reform Act of 1994, Pub. L. No. 103-394, 108 Stat. 4106 (1994). The new law authorizes the creation of a "Bankruptcy Review Commission" to study the bankruptcy system and recommend changes. See id. $\$ \S 601-10,108$ Stat. at 4147-50.
} 
prevail is unknown. The government, in fact, keeps only very rudimentary statistics on bankruptcy cases. ${ }^{149}$ As a result, any argument that Congress needs to tighten or loosen the prevailing standards must rest heavily on speculation.

The following sections, however, recommend two minor reforms. First, Congress should enact new legislation to discourage counsel from intentionally or inadvertently advising clients to commit bankruptcy fraud. Second, Congress should amend the Bankruptcy and Criminal Codes to clarify the proper treatment of the reliance on advice of counsel argument.

\section{A. DisCOURAGng IMPROPER AdVICE}

Congress tends to evaluate legislation from two policy perspectives: the ex post and the ex ante. ${ }^{150}$ The ex post perspective asks whether legal rules produce fair results. ${ }^{151}$ The ex ante perspective, by contrast, asks how legal rules affect behavior. ${ }^{152}$ Although some senators or representatives may feel that one perspective has more force or legitimacy than the other, both approaches may influence Congress if it takes up the subject of consumer bankruptcy fraud.

In the author's view, the ex post perspective does not suggest a need for any particular reforms. The current statutes treat debtors in a reasonably fair manner. The consequences to debtors who are caught committing harmful acts with a malevolent intent usually are appropriate. Furthermore, debtors who act innocently, including debtors who act in reliance on advice of counsel, are generally not sanctioned. Creditors and debtors can live happily with this balanced arrangement.

The ex ante perspective, however, suggests that the current law regarding reliance on advice of counsel might have an unfortunate effect on behavior. In particular, the possibility that a debtor can use the reliance argument to escape punishment gives attorneys a perverse incentive to provide their clients with inaccurate advice. If debtors cannot be punished for lying or stealing on the advice of counsel, attorneys may have a motivation to tell them to do just that. The debtors, in many cases, will end up better off by acting in ways that hurt their creditors.

Here is an example: Suppose a debtor asks a lawyer whether to list a new car as an asset on a bankruptcy schedule. The law clearly requires the car's disclosure. If the debtor lists the car, however, the trustee will take the vehicle and sell it for the benefit of creditors. The debtor, accordingly, will lose the car.

\footnotetext{
14T The Administrative Office of the United States Courtskeeps statistics on the number of bankruptcy cases filed each year. It also keeps track of which chapter of the Bankruptcy Code governs each case and whether the debtor is an individual or a business. See, e.g., Director of THE AdMIN. OfFICE OF THE UNITED StATES Courts ANN. ReP. app. 1, at 92-97 (1989).

${ }^{150}$ For an exceptionally lucid explanation of these perspectives, see Frank H. Easterbrook, The Supreme Court, 1983 Term - Foreword: The Court and the Economic System, 98 HaRv. L. Rev. 4, 10-12 (1984). See also Jason S. Johnston, Uncertainty, Chaos, and the Torts Process: An Economic Analysis of Legal Form, 76 CoRNELL L. REv. 341, 347 (1991); Laurence H. Tribe, Constitutional Calculus: Equal Justice or Economic Efficiency?, 98 HARV. L. ReV. 592, 593 (1985).

${ }^{15}$ Easterbrook, supra note 150 , at 11.

${ }^{152} I d$.
} 
Because of the rules regarding reliance on advice of counsel, a lawyer might decide to advise the debtor not to list the car. If the bankruptcy trustee never finds out about the automobile, the client can keep it. If the trustee does learn about the vehicle, the client will lose it, but can use the reliance argument to escape further punishment. In other words, improper advice not to list the car has a potential upside for the client (i.e., the client keeps the car) and no downside (i.e., the client loses the car just as if he or she had listed it in the first place). Any unethical lawyer who wants to satisfy a client knows exactly what to do in this situation.

Bankruptcy lawyers, at present, have very little to fear when they give their clientserroneous advice. Their clients will have no reason to sue them for malpractice because the reliance argument can minimize the debtor's exposure to any civil or criminal liability. One court, in fact, has noted that the reliance argument has created in attorneys a "willingness to bear the burden of reproach."153 This willingness manifests itself in a dialogue summarized by another bankruptcy court as follows: When a court suspects bankruptcy fraud, "Debtor [typically] replies, 'It is a mistake; and counsel says, 'Blame me, not the debtor-it was due to mistake and inadvertence.' "154 The lawyer can admit to making an error because he or she knows that client will not do anything about it.

In theory, lawyers who assist clients in committing bankruptcy fraud face the possibility of disciplinary action, even if they do not have to fear malpractice suits. Most states have ethical rules permitting bar officials to punish attorneys who intentionally advise clients to engage in prohibited conduct. ${ }^{155}$ In addition, the bankruptcy courts may impose sanctions on attorneys who file false or frivolous documents. ${ }^{16} \mathrm{M}$ Moreover, as noted above, attorneys can be prosecuted under the Criminal Code for participating in bankruptcy fraud.

Disciplinary actions against bankruptcy attorneys, however, seldom occur for two reasons. First, state bars and federal law enforcement agencies have very limited resources. They learn about bankruptcy fraud mostly through referrals and they usually have more serious matters to address. ${ }^{157}$ Second, charges against attorneys may be difficult to prove. Merely showing that an attorney gave bad advice does not suffice; the prosecutor also must demonstrate, at a minimum, that the lawyer knew that advice was wrong. It is often difficult to obtain such evidence. ${ }^{158}$

Perhaps increasing efforts to discipline wayward lawyers would ameliorate the situation. Indeed, evencatching a few more lawyerseach year might make a significant

\footnotetext{
${ }^{153}$ Boroff v. Tully (In re Tully), 818 F.2d 106, 111 (1st Cir. 1987).

${ }^{154}$ Raymos v. Collins (In re Collins), 19 B.R. 874, 877 (Bankr. M.D. Fla. 1982).

${ }^{155}$ See, e.g., Model Rules of Professional Conduct Rule 1.2(d)(1983)( ( A lawyer shall not counsel a client to engage, or assist a client, in conduct that the lawyer knows is criminal or fraudulent ...); id. Rule 3.4 (" A lawyer shall not ... counsel or assist a witness to testify falsely ...").

${ }^{156} \mathrm{See}$ FED. R. BANKR. P. 9011.

${ }^{157}$ See supra text accompanying notes $30-33$.

${ }^{158}$ See Barker v. Henderson, Franklin, Starnes \& Holt, 797 F.2d 490, 496 (7th Cir. 1986) (depicting the difficulty of showing that a law firm acted with scienter).
} 
difference. As noted above, a single lawyer often is responsible for dozens of questionable cases. ${ }^{159}$ Moreover, if attorneys merely perceive an increased threat, they may modify their behavior. As one United States Trustee recently, remarked, "If word gets out that these cases are going to be brought, the offenders will get nervous and be more careful." 160

Whether or not responsible agencies step up their enforcement efforts under existing laws, Congress might improve the situation by enacting new legislation. The author suggests the following two modest and inexpensive ways to lessen the incentives that lawyers now have to counsel their clients to commit fraud.

\section{Require Debtors to Act Reasonably}

Congress could reduce the incentive of lawyers togiveimproper advice to clients by enacting legislation making reasonableness a required element of the reliance argument. In other words, Congress could amend the Bankruptcy Code to provide that, in connection with an argument that the debtor relied on the advice of counsel, to prevail the debtor must show that a reasonable person would have believed the advice. A requirement of reasonableness would increase the likelihood that courts would punish debtors for following inappropriate advice, and thus discourage lawyers from providing it.

Experience already has shown that a reasonableness requirement can produce workable results. As noted above, many courts (although sometimes incorrectly under current law) have required debtors to act reasonably, without noticeably harmful effects. Moreover, as an added benefit, a reasonableness standard often may eliminate extensive litigation over what debtors subjectively believed at the time that they transferred assets or lied on their bankruptcy forms.

A reasonableness requirement admittedly has some drawbacks. Most significantly, although it might dissuade lawyers from intentionally counselling debtors to commit fraudulent acts, it would penalize debtors who act innocently but unreasonably. A few debtors, after all, might follow advice that no ordinary person would accept simply because of their inexperience or lack of knowledge. These debtors could not use the reliance argument and would face punishment.

Congress, however, could limit the unfairness to innocent debtors by requiring reasonableness only in cases in which debtors raise the reliance argument to avoid a denial of discharge (as opposed to criminal penalties). Debtors who lose their discharges after following an attorney's advice can sue their attorneys for malpractice. Because lawyers generally have resources to pay, these actions might remedy any harm the debtor suffers.

\section{Require Debtors and their Attomeys to Sign a New “Bankruptcy Fraud} Disclosure Form"

Second, Congress should require debtors to file a new standard form when they

${ }^{159}$ See Grunbaum, supra note 17 , at 1.

${ }^{160}$ Walsh, supra note 30 , at AI. 
declare bankruptcy. At present, debtors must fill out an array of forms and schedules when they file a bankruptcy petition. ${ }^{161}$ These forms and schedules require debtors to disclose information about their assets and debts, but say very little about bankruptcy fraud. A new form, possibly called the "Bankruptcy Fraud Disclosure Form" ("Form"), could supplement these existing forms.

The Form, as the author envisions it, would describe in plain language on a single piece of paper the Bankruptcy Code's disclosure requirements and the most common forms of bankruptcy fraud. It would then list and explain the possible civil and criminal penalties for bankruptcy fraud. ${ }^{162}$ Finally, the Form would require the signature of the debtor and the debtor's counsel to indicate that they have read and understood the disclosures.

The Form could help to reduce fraud in two ways. First, it might educate many debtors and lawyers about the law. At present, lawyers are not required to have any knowledge of bankruptcy law to practice bankruptcy law. Instead, anyone admitted to practice before a district court may practice in the district's bankruptcy court. ${ }^{163}$ As a result, some lawyers actually may counsel clients toengage in prohibited conduct simply because they do not know any better.

Second, and perhaps more significantly, the Form would undermine efforts by attorneys and clients to escape punishment for bankruptcy fraud by falsely claiming ignorance of the law. The mere existence of the Form would weaken the credibility of attorneys who, when charged with assisting clients to commit bankruptcy fraud, allege that they did not understand the law and simply made a mistake. If a lawyer has read and signed a form explaining the basic rules regarding bankruptcy fraud, the lawyer will have difficulty attempting to characterize improper advice as an error.

The Form would impose minimal costs on lawyers, clients, and the judicial system. The Form probably would take only a few minutes for each debtor to read and sign, and thus would not affect the cost of bankruptcy representation very much. ${ }^{164}$ Bankruptcy court clerks could easily examine filings to make sure that every petition included a completed Form.

Needless to say, the Form would not eliminate bankruptcy fraud altogether. Many debtors will ignore the Forms even after signing them. Some will not understand the rules no matter how clearly they are stated. Others will defraud creditors in ways not covered by the Form. Still others already will have committed the fraud

\footnotetext{
${ }^{161}$ See, e.g., Fed. R. Bankr. P. Forms 1, 6, 7.

${ }^{162}$ Bankruptcy Form 6 already contains the brief statement: "Penalty for making false statement or concealing property. Fine of up to $\$ 500,000$ or imprisonment for up to 5 years or both. 18 U.S.C. $\$ \S 152$ and 3571 ." Id. Form 6.

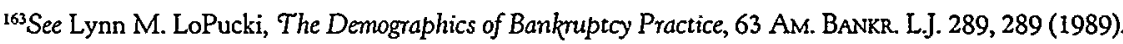
Admission to a district court usually involves little more than demonstrating membership in the state bar. Id.

${ }^{16}$ Another possible way to help ensure that lawyers do not provide erroneous advice to clients would be to require all bankruptcy attorneys to obtain some kind of certification in bankruptcy. Although this requirement might produce better educated bankruptcy lawyers, it also might reduce the size of the bankruptcy bar. It may also unjustifiably drive up the price for bankruptcy representation.
} 
before receiving the information stated in the Form.

Yet, experience suggests that the procedure may help to some extent. The Bankruptcy Code already contains similar briefing requirements in two different contexts. At present, a debtor cannot reaffirm a discharged debt unless the debtor's attorney signs an affidavit stating that the attorney has informed the debtor fully that the debtor has no legal obligation to reaffirm. ${ }^{165}$ In addition, Congress recently imposed a new requirement that bankruptcy trustees review with debtors certain issues, including the potential consequences of bankruptcy on credit history and the ability to choose different chapters of the Bankruptcy Code. ${ }^{166}$ To the extent that these procedures prevent imprudent bankruptcy filings or reaffirmation agreements, a similar requirement also might reduce the incidence of bankruptcy fraud.

\section{B. Indicating How Courts Should Treat the Reliance Argument}

Even if Congress decides not to modify the existing rules concerning the reliance argument in the ways suggested, it may wish to make them clearer. As noted above, the present statutes do not create a separate advice of counsel defense. Instead, evidence that the debtor has received legal advice is relevant because it bears on the question whether the debtor acted knowingly, fraudulently, or with some other similar intent. The present system has much to say in its favor; indeed, it has survived for over a hundred years in several bankruptcy laws.

Congress, however, may wish to consider rewriting the statutes to create a separate advice of counsel defense. For example, it could add a separate provision to $\S 727$ of the Bankruptcy Code or $\$ 152$ of the Criminal Code stating explicitly that reliance on advice of counsel will excuse conduct that otherwise would warrant denial of a discharge. In this section, it could list any elements, such as good faith or reasonableness, that the debtor would have to show.

There are several arguments in favor of stating the defense explicitly in the statute. First, it would promote uniformity in applying the defense. As noted above, although some courts have properly determined how to take legal advice into account under the Bankruptcy and Criminal Codes, many havenot. The courts that have been struggling to create an affirmative defense apart from the statute would benefit by having the proper rules spelled out for them in a clear manner.

Second, a separate defense would have several practical advantages. For example, a separate defense would allow Congress to state with greater specificity the effect of advice of counsel. At present, as noted above, courts must discern the statutory requirements by looking at a few words such as "knowingly" or "fraudulently." A separate defense could include much more detail. In addition, listing all of the required showings in a single section would facilitate any efforts to alter the standards if new information suggested the need for modification.

\footnotetext{
${ }^{165}$ See 11 U.S.C. $\$ 525(\mathrm{c})(3)$ (1988).

${ }^{16}$ See Bankruptcy Reform Act of 1994, Pub. L. No. 103-394, sec. 115, 108 Stat. 4106, 4118-19 (to be codified at 11 U.S.C. \$341(d)).
} 
Finally, experience has shown the feasibility of stating an advice of counsel defense. The best example comes from regulations promulgated by the Treasury Department. For years, taxpayers have contested penalties imposed by the Internal Revenue Service ("IRS") for errors in their tax returns on grounds they filed the returns on the advice of counsel. The IRS has responded by enacting several regulations that specify when the defense should work and when it should not. ${ }^{167}$

One regulation, for example, requires the tax adviser to provide an opinion that "unambiguously states there is a greater than 50-percent likelihood that the tax treatment of the item will be upheld in litigation if the claimed tax treatment is challenged by the Internal Revenue Service." 168 Another requires the taxpayer to make full disclosure of all material facts and requires the tax adviser to give reasons for the opinion. ${ }^{169}$

\section{CONCLUSION}

The foregoing discussion has sought to show how courts should deal with the reliance argument in consumer bankruptcy fraud cases. Although the Bankruptcy and Criminal Codes do not spell out the effect of a debtor's reliance on the advice of counsel in the clearest terms, courts in bankruptcy should treat it much as courts outside of bankruptcy have historically treated the argument. Although Congress may wish to change the existing law in modest ways, it has no need to make sweeping changes at this time.

Resolving the current disagreement over when debtors can escape punishment for misconduct in bankruptcy cases by arguing that they relied on the advice of counsel will not eliminate fraud from the consumer bankruptcy system. Understanding the role that attorneys can play in bankruptcy fraud, however, should help in developing better means of preventing it.

\footnotetext{
${ }^{167}$ See, e.g, Substantial Understatement of Income Tax, 26 C.F.R. § 1.6662-4(g)(4)(ii)(1993); Imposition of Initial Taxes, 26 C.F.R. $\$ 53.4941$ (a)-(1)(b)(6) (1993). See generally Marguerite R. Hutton, When is Reliance on a Tax Advisor Reasonable Cause for Waiving Penalties, 71 J. TAX'N 330 (1989).

${ }_{168} 26$ C.F.R. $\$ 1.6662-4(\mathrm{~g})(4)(\mathrm{ii})$.

${ }^{169} I d . \$ 53.4941(\mathrm{a})-(1)(\mathrm{b})(6)$.
} 